\title{
Ameliorative Effect of Hexane Extract of Phalaris canariensis on High Fat Diet-Induced Obese and Streptozotocin-Induced Diabetic Mice
}

\author{
Rosa Martha Perez Gutierrez, ${ }^{1}$ Diana Madrigales Ahuatzi, ${ }^{2}$ Maria del Carmen Horcacitas, ${ }^{3}$ \\ Efren Garcia Baez, ${ }^{4}$ Teresa Cruz Victoria, ${ }^{2}$ and Jose Maria Mota-Flores ${ }^{1}$ \\ ${ }^{1}$ Laboratorio de Investigación de Productos Naturales, Escuela Superior de Ingenieria Quimica e Industrias Extractivas, \\ Instituto Politecnico Nacional, Avenida Instituto Politécnico Nacional S/N, Unidad Profesional Adolfo Lopez Mateos, \\ 07708 Mexico D.F., Mexico \\ ${ }^{2}$ Departamento de Alimentos, Escuela Nacional de Ciencias Biologicas, IPN Carpio S/N, 11340 Mexico D.F., Mexico \\ ${ }^{3}$ Departamento de Biotecnología y Bioingenieria, CINVESTAV, Avenida IPN S/N, 07360 Mexico D.F., Mexico \\ ${ }^{4}$ Departamento de Ciencias, Basicas Unidad Profesional de Biotecnologia IPN, Avenida Acueducto S/N, 07340 Mexico D.F., Mexico
}

Correspondence should be addressed to Rosa Martha Perez Gutierrez; rmpg@prodigy.net.mx

Received 11 May 2013; Revised 21 November 2013; Accepted 27 November 2013; Published 9 January 2014

Academic Editor: Musa T. Yakubu

Copyright (C) 2014 Rosa Martha Perez Gutierrez et al. This is an open access article distributed under the Creative Commons Attribution License, which permits unrestricted use, distribution, and reproduction in any medium, provided the original work is properly cited.

\begin{abstract}
Obesity is one of the major factors to increase various disorders like diabetes. The present paper emphasizes study related to the antiobesity effect of Phalaris canariensis seeds hexane extract (Al-H) in high-fat diet- (HFD-) induced obese CD1 mice and in streptozotocin-induced mild diabetic (MD) and severely diabetic (SD) mice.AL-H was orally administered to MD and SD mice at a dose of $400 \mathrm{mg} / \mathrm{kg}$ once a day for 30 days, and a set of biochemical parameters were studied: glucose, cholesterol, triglycerides, lipid peroxidation, liver and muscle glycogen, ALP, SGOT, SGPT, glucose-6-phosphatase, glucokinase, hexokinase, SOD, CAT, GSH, GPX activities, and the effect on insulin level. HS-H significantly reduced the intake of food and water and body weight loss as well as levels of blood glucose, serum cholesterol, triglyceride, lipoprotein, oxidative stress, showed a protective hepatic effect, and increased HDL-cholesterol, serum insulin in diabetic mice. The mice fed on the high-fat diet and treated with AL-H showed inhibitory activity on the lipid metabolism decreasing body weight and weight of the liver and visceral adipose tissues and cholesterol and triglycerides in the liver. We conclude that AL-H can efficiently reduce serum glucose and inhibit insulin resistance, lipid abnormalities, and oxidative stress in MD and SD mice. Our results demonstrate an antiobesity effect reducing lipid droplet accumulation in the liver, indicating that its therapeutic properties may be due to the interaction plant components soluble in the hexane extract, with any of the multiple targets involved in obesity and diabetes pathogenesis.
\end{abstract}

\section{Introduction}

Obesity is a metabolic disease of pandemic proportions largely arising from positive energy balance, a consequence of sedentary life style, conditioned by environmental and genetic factors [1]. Obesity results from an imbalance between energy intake and expenditure. It is often associated with chronic diseases such as hyperlipidemia, hvpertension and noninsulin- dependent diabetes mellitus and with increased risk of coronary heart diseases [2]. It has been reported that variations in total energy intake and diet composition are important in the regulation of metabolic processes [3]. Excessive accumulation of lipids in nonadipose tissues such as liver, heart, skeletal muscle, kidney, and pancreas contributes to the pathogenesis of fatty liver, heart failure, and insulin resistance with the so-called lipotoxicity mechanism, fatty liver is an early hallmark of nonalcoholic fatty liver disease [4], the most common chronic liver disease associated with insulin resistance, obesity and type 2 diabetes [5].

Adipose tissue, besides its primary function of fat storage, also regulates appetite and metabolism by secretion of certain chemicals like an endocrine gland [6]. Thus, persistent insulin 
resistance and hyperglycemia lead to the development of diabetes mellitus type 2 (T2DM) [7]. Furthermore, the metabolic syndrome develops atherosclerotic diseases, whose fatality is very high, when the symptom gets worse [8]. It is therefore important to prevent or abate obesity. A growing number of enzymes involved in lipid metabolic pathways are being identified and characterized. They represent a rich pool of potential therapeutic targets for obesity [9]. Triglyceride (TG) metabolism is regulated by several factors such as TG intake from food and synthesis and oxidation in various tissues. Among these factors, the hydrolysis of TG by lipoprotein lipase to free fatty acids is an important determinant in TG metabolism [10]. Canary seed is solely used as food for caged and wild birds. However, the unique composition and characteristics of canary seed make it a promising cereal for food and industrial uses [11]. In the past, canary seed was not seen as a viable cereal for human consumption due to the harmful effects associated with the siliceous hairs that cover the hull of the seed. These hairs are highly irritating when they come in contact with human skin or lungs and have been linked to esophageal cancer [12]. In 1997 CDC Maria was registered in Canada as the first hairless cultivar eliminating the potential health risk associated with hairy varieties [13]. The variety was developed based on mutagenesis and traditional breeding by which a totally hairless variety was developed. Removing the damaging hairs rediscovered canary seed as a potential food crop and industrial crop for fractionation industry.

The canary seed or alpiste, Phalaris canariensis L., is a member of a family of grasses (Graminaceae), and it is used in folk medicine in the form of tea as a coadjuvant in the treatment of hypertension, diabetes mellitus, and hypercholesterolemia [14], with or without other forms of traditional therapy [15]; however, such use has no scientific basis. There is only one study related to the hypotensive effect of $P$. canariensis seed infusion in normotensive rats [16]; however, its therapeutic use as an antihypertensive agent and its possible mechanisms of action have not been scientifically demonstrated. The aim of the present study was to establish antiobesity and antidiabetic activities of the seeds of Phalaris canariensis.

\section{Materials and Methods}

2.1. Plant Material. Seeds of $P$. canariensis were collected in Morelos State, Mexico. A voucher specimen (number 8054) was deposited in the Herbarium of the National School of Biological Sciences, for further reference.

\subsection{Preparation of Plant Extracts. A total of $1000 \mathrm{~g}$ of} the seeds of $P$. canariensis were dried and powdered in a mechanical grinder. The grinded material was extracted with $5 \mathrm{~L}$ of hexane, chloroform, and methanol consecutively using a soxhlet apparatus. These extracts were filtered and concentrated by a rotary vacuum evaporator and kept in a vacuum desiccator for complete solvent removal.

2.3. Animals. The study was conducted in CD1 mice of both sexes, weighing about 25-30 g. Before and during the experiment, animals were fed a standard laboratory diet (Mouse Chow 5015, Purina) with free access to water. Mice were procured from the bioterium of ENCB and were housed in microloan boxes in a controlled environment (temperature $25 \pm 2^{\circ} \mathrm{C}$ ). Animals were acclimatized for a period of three days in their new environment before the initiation of experiment. Litter in cages was renewed three times a week to ensure hygiene and maximum comfort for animals. The experiments reported in this study were carried following the guidelines stated in Principles of Laboratory Animal Care National Institute of Health publication (NIH) publication 85-23, revised 1985 and the Mexican Official Normativity (NOM-062-Z00-1999). All animals procedures were performed in accordance with the recommendations for the care and use of laboratory animals (756/lab/ENCB).

2.4. Mouse Model of Diet-Induced Obesity. Thirty-five male CD1 mice, 2 months old and weighing between 20 and $25 \mathrm{~g}$, were acclimatized under room temperature $\left(28 \pm 2^{\circ} \mathrm{C}\right)$ with a regular light/dark cycle and free access to food and water for 1 week before use. Following acclimatization, the animals were randomly segregated into five groups of seven rats each. We formulated experimental high-fat diets consisting of $50 \%$ normal rat chow pellet, $24 \%$ corn oil, $20 \%$ full-cream milk powder, and 6\% sugar, as suggested by Martinello et al. [17]. Another group, noted as normal control (NC), was given normal rat chow. After the induction period, the mean body weights of the high-fat diet-treated groups were compared with the NC group. Groups with significantly higher mean body weights than the NC group were considered to be obese and were used in the subsequent 10 weeks of experimentation with $P$. canariensis extracts. Each extract at dose $400 \mathrm{mg} / \mathrm{kg}$ was prepared by dissolving in $1 \%$ of Tween 80 . The supplementations were given daily via oral gavage for 10 weeks, at a volume of $0.1 \mathrm{~mL}$. The $\mathrm{NC}$ and obese control (OC) groups were given distilled water as a placebo.

2.5. Supplementation of $P$. canariensis. Treatment with extracts began after 10 weeks of obesity induction and scored until week 10. Two different doses of $P$. canariensis were used in the experiment: 200 and $400 \mathrm{mg} / \mathrm{kg}$. The extracts were prepared by dissolving in $1 \%$ of Tween 80 . The supplementations were given daily via oral gavage for 10 weeks, at a volume of $0.1 \mathrm{~mL}$. The NC and obese control (OC) groups were given distilled water as a placebo. Contrary from the induction period, all groups were given normal rat chow throughout the treatment period.

2.6. Induction of Severe Diabetes (SD). Severe diabetes was induced in overnight fasting male mice by a single intraperitoneal injection of $50 \mathrm{mg} / \mathrm{kg}$ of streptozotocin in a volume $1 \mathrm{ml} / \mathrm{kg}$ body weight dissolved in cold citrate buffer $(\mathrm{pH} 4.5)$ [18]. Hyperglycemia was confirmed by measuring glucose $72 \mathrm{~h}$ after the streptozotocin shot and 7 days after injection, confirming a high glucose level. Mice with permanent high 
fasting blood glucose level $>300 \mathrm{mg} / \mathrm{dl}$ were included in the experiments.

2.7. Induction of Mild Diabetes (MD). Mild diabetes was induced in overnight fasting mice by administering a single intraperitoneal injection of $60 \mathrm{mg} / \mathrm{kg}$ b.w. STZ in $0.1 \mathrm{~mol} / \mathrm{L}$ cold citrate buffer ( $\mathrm{pH} 4.5), 15 \mathrm{~min}$ after the intraperitoneal administration of $120 \mathrm{mg} / \mathrm{kg}$ nicotinamide. The STZ treated animals were allowed to drink $5 \%$ glucose solution overnight to overcome drug induced hypoglycemia. After 10 days of development of diabetes, mice with moderate diabetes having persistent glycosuria and hyperglycaemia (blood glucose $>250 \mathrm{mg} / \mathrm{dl}$ ) were used for further experimentation [19].

\subsection{Experimental Design in Diabetic Mice}

2.8.1. Effect of Single Oral Administration of Extracts of P. canariensis in Glucose Level in Severe and Mild Diabetic Mice. After the mice had been denied access to food/water overnight, they were randomly divided into eight groups (six mice per group) matched for body weight. Normal mice administered distilled water daily for 30 days. Diabetic control mice administered distilled water daily for 30 days. Diabetic mice administered extract of hexane $(100 \mathrm{mg} / \mathrm{kg})$, for 30 days. Diabetic mice administered extract of hexane $(200 \mathrm{mg} / \mathrm{kg})$, for 30 days. Diabetic mice administered extract of hexane $(400 \mathrm{mg} / \mathrm{kg})$, for 30 days. The other diabetic groups were orally administered 100,200 and $400 \mathrm{mg} / \mathrm{kg}$ body weight (b.w.) of extracts of chloroform (AL-C) and methanol (ALM) suspended in Tween 80 , 1\% via gavage). Diabetic treated mice received glibenclamide (GB) a dose of $5 \mathrm{mg} / \mathrm{kg}$ b.w as standard drug. Blood samples were collected from the tail vein at $0,2,4,6,8$, and $12 \mathrm{~h}$ after the administration. The plasma glucose concentration was determined by an enzymatic colorimetric method using a commercial kit (Sigma Aldrich, USA).

2.8.2. Antidiabetic Test in Chronic Severe and Mild Streptozotocin-Induced Diabetic Mice. In a parallel study eleven groups $(n=10)$ of diabetic mice were used to determine the chronic effect of AL-H extract. Each group was submitted to a specific treatment as follows. Normal control and severe and mild diabetic mice groups were fed with normal diet and drinking water ad libitum and were given saline by gastric gavage. Severe and mild diabetic mice that received Al-H extract by gastric gavage ( $400 \mathrm{mg}$ per $\mathrm{kg}$ of body weight) every day [7] were designated as $\mathrm{SD}+\mathrm{Al}-\mathrm{H}$ and $\mathrm{MD}+\mathrm{AL}-\mathrm{H}$ groups. Two groups with severe $(\mathrm{SD}+\mathrm{GB})$ and mild diabetes $(\mathrm{MD}+\mathrm{GB})$ mice were administered with glibenclamide (GB) $4 \mathrm{mg} / \mathrm{kg}$ as positive control.

2.8.3. Determination of Body Weight and Food Intake. The final body weight showed significant increase from the initial body weight in all the groups except in the diabetic group, in which there was significant decrease in body weight compared to the initial body weight (Table 5).
The body weight of each mouse was measured once each week and the total amount of food consumed was recorded 3 times per week.

2.8.4. Collection of Organ Tissues. At the end of obesity and chronic diabetes experiments all mice were anesthetized with $1.0 \%$ pentobarbital sodium and blood was obtained from the retroorbital plexus of each animal following the injection of heparin (100 IU kg-1 body weight) into a tail vein for $10 \mathrm{~min}$ [20]. The liver and kidney were removed according to defined anatomical landmarks [21].

2.8.5. Plasma Biochemical Analysis. Blood samples were collected from tail vein of the mice into microcentrifuge tubes containing heparin $\left(10 \mu \mathrm{L}, 1000 \mathrm{IU} \mathrm{mL}^{-1}\right)$. The blood samples were then centrifuged at $1600 \times \mathrm{g}$ for $15 \mathrm{~min}$ at $4^{\circ} \mathrm{C}$ for the preparation of plasma. Concentrations of plasma glucose, total cholesterol (TC), triglycerides (TG), and HDLcholesterol were measured with enzymatic assay kit (Genzyme Diagnostics), and LDL-cholesterol was calculated as the remaining difference of total cholesterol and HDL. Blood glucose levels were measured employing the glucose oxidaseperoxidase (GOD-POD) method [22]. Lipid peroxidation, that is, thiobarbituric acid reactive substances (TBARS), was estimated by the method of Fraga et al. [23] and expressed as $\mu \mathrm{M} / \mathrm{g}$ of liver and kidney tissue. Serum glutamate oxaloacetate transaminase (SGOT), glutamate pyruvate transaminase (SGPT), serum alkaline phosphatase (SALP), and total protein, using a commercial Diagnostic Kit Biocompare, BioVision, Biocompare and Thermo scientific, respectively. Malondialdehyde (MDA) as thiobarbituric acid reactive substances was measured at $532 \mathrm{~nm}$ spectrophotometrically [24].

2.8.6. Oral Glucose Tolerance Test. Mice of each group were orally administered $P$. canariensis aqueous extracts at doses of $400 \mathrm{mg} / \mathrm{kg}$ body weight on a daily basis for 30 days. At the end of the experiment, an oral glucose tolerance test (OGTT) was performed to assess the animals's sensitivity to a high glucose load. Overnight fasting mice were fed orally $2 \mathrm{~g}$ glucose $/ \mathrm{kg}$ b.w. Blood samples were collected from the caudal vein from a small incision at the end of the tail at $0 \mathrm{~min}$ (immediately after glucose load), 30, 60, 90, and $120 \mathrm{~min}$ after glucose administration.

2.8.7. Assay of Glycogen Content in Liver and Skeletal Muscle. Mice were sacrificed by decapitation; livers and kidneys were extracted. Frozen livers were thawed, weighed, and homogenized in Tris- $\mathrm{HCl}(5 \mathrm{mmol} / \mathrm{L}, \mathrm{pH}$ 7.4) buffer containing $2 \mathrm{mmol} / \mathrm{L}$ EDTA. Homogenates were centrifuged at $1000 \times \mathrm{g}$ for $15 \mathrm{~min}$ at $4^{\circ} \mathrm{C}$. The supernatant was mixed with glucose-6-phosphate dehydrogenase and NADPH and the activity of hexokinase was determined at $37^{\circ} \mathrm{C}$ for $3 \mathrm{~min}$ at $30 \mathrm{~s}$ intervals at $340 \mathrm{~nm}$ [25] The hepatic glycogen content was measured according to the anthrone- $\mathrm{H}_{2} \mathrm{SO}_{4}$ method [26]. Briefly, liver tissue (64-144 mg) was homogenized in five volumes of an ice-cold $30 \% \mathrm{KOH}$ solution and the homogenate was placed in a boiling water bath $\left(100^{\circ} \mathrm{C}\right)$ for $20 \mathrm{~min}$. The glycogen was redissolved in distilled water 
and treated with an anthrone reagent $(2 \mathrm{~g}$ anthrone/ $\mathrm{L}$ of $\left.95 \%(\mathrm{v} / \mathrm{v}) \mathrm{H}_{2} \mathrm{SO}_{4}\right)$ and the absorbance was measured at $620 \mathrm{~nm}$.

2.8.8. Assay of G6Pase Activity in Liver. The hepatic G6Pase (glucose-6-phosphatase) activity was assayed by the method of Baginiski et al. [27]. Shortly, the glucose-6-phosphate in the liver extract was converted into glucose and inorganic phosphate. The inorganic phosphate liberated was determined with ammonium molybdate; ascorbic acid was used as the reducing agent. Excess molybdate was removed by the arsenite-citrate reagent, so that it could no longer react with other phosphate esters or with inorganic phosphate formed by acid hydrolysis of the substrate. The amount of phosphate liberated per time unit, determined as the blue phosphormolybdous complex at $700 \mathrm{~nm}$, was a measure of the glucose6-phosphatase activity. The protein content of the liver extract was quantified by Bradford reaction (Bio-Rad protein assay kit) [28]. The G6Pase activity (mU) was expressed as mmol of phosphate released $/ \mathrm{min} / \mathrm{mg}$ of protein.

2.8.9. Assay GK Activity in Liver. Glucokinase (GK) activity was measured using a spectrophotometric method as previously described by Panserat et al. [29]. Briefly, liver tissues were homogenized and the supernatant obtained by centrifugation was supplemented with $1 \mathrm{mM}$ NADP, $5 \mathrm{mM}$ ATP, and 100 or $0.5 \mathrm{mM}$ glucose at $\mathrm{pH} 7.5$. The enzymatic reaction was started by the addition of 0.2 unit of glucose6-phosphate dehydrogenase (E.C.1.1.1.49) and incubated for 5 min at $37^{\circ} \mathrm{C}$. NADPH generated by GK was measured using a spectrophotometer at $340 \mathrm{~nm}$. GK activity was estimated by the standard method, that is, subtracting the rate of NADPH formation in the presence of $0.5 \mathrm{mM}$ glucose from that obtained in the presence of $100 \mathrm{mM}$ glucose [30]. Protein concentration was quantified by Bradford and one unit of enzyme activity ( $\mathrm{mU}$ ) was defined as mmol of substrate molecules converted by $1 \mathrm{mg}$ protein per minute. GK activity was estimated as the difference in activity when samples were assayed at $100 \mathrm{mmol} / \mathrm{L}$ (GK plus hexokinase activity) and $0.5 \mathrm{mmol} / \mathrm{L}$ glucose (hexokinase activity).

2.8.10. Measurement of Antioxidant and Lipid Peroxidation Parameters. After 30 days of treatment, mice fasted overnight and euthanized by anesthesia. Antioxidant enzyme activities in the liver, pancreas, and kidney were assayed using commercial kits: superoxide dismutase (SOD) assay kit Bioxytech SOD-525 for SOD activity (Oxis International), catalase assay kit for catalase activity (CAT) (Cayman Chemical), glutathione reductase (GSH) assay kit Bioxytech GR-340 for GR activity (Oxis International), glutathione peroxidase (GPx) assay kit GPx-340 for GPx (Oxis International), and lipid peroxidation using malondialdehyde level by commercial kit (TBARS assay kit). In the pancreas the protein concentration was determined by the Bradford method as described in the Bio-Rad protein assay kit.

2.8.11. Extraction of Hepatic Lipids. After removal from the animals, parts of the samples of fresh liver were collected for analyzing the lipid content. The liver (1.25 g) was homogenized with chloroform/methanol $(1: 2,3.75 \mathrm{~mL})$, and then chloroform $(1.25 \mathrm{~mL})$ and distilled water $(1.25 \mathrm{~mL})$ were added to the homogenate and mixed well. After centrifugation $(1500 \times \mathrm{g}$ for $10 \mathrm{~min})$, the lower clear organic phase solution was transferred into a new glass tube and then lyophilized. The lyophilized powder was dissolved in chloroform/methanol $(1: 2)$ as the hepatic lipid extracts and stored at $-20^{\circ} \mathrm{C}$ for less than 3 days [31]. The hepatic cholesterol and triglycerides in the lipid extracts were analyzed with the diagnostic kits used for the plasma analysis.

2.8.12. Determination of Insulin. Diabetic mice serum and pancreatic insulin were measured by a Glazyme Insulin-EIA Test according to the manufacturer's instructions [32]. Blood samples and pancreas were taken for insulin determination. The level of insulin in serum was expressed in $\mu \mathrm{IU} / \mathrm{mL}$.

2.8.13. Statistical Analysis. Statistical analysis was carried out by using commercially available software SigmaStat 3.5. Values are expressed as mean \pm SEM. For multiple comparisons, one-way ANOVA was used followed by Tuckey and Dunnett's test. $P$ value $<0.05$ was considered to be significant.

\section{Results}

Treatment with chloroform and methanol extracts did not significantly inhibit the rise in blood glucose levels in normal and diabetic mice and in oral glucose tolerance. However, mice fed the high-fat diet treated with hexane, chloroform, and methanol extracts showed a decrease similarly; for this reason it was decided to study only hexane extract due to the fact that it presents hypoglycemic and antiobesity activities. However, chloroform and methanol extracts did not.

3.1. Effects of the High-Fat Diet (HFD) on Body Weight and Food Intake. The body weights and food intake are shown in Table 1. No significant difference in food intake was observed throughout the obesity induction period in all groups. Body weight of all groups was significantly increased compared with the control group after 10 weeks of feeding.

\subsection{Effect of P. canariensis Extracts on the Weight of Organs} and Adipose Tissue. The mice fed on the high-fat diet for 10 weeks had a significantly higher body weight and significantly heavier visceral adipose tissues than the mice fed on the normal diet. In the mice fed on the high-fat diet, the body weight elevation that took place over the initial 6 weeks on the high-fat diet was significantly reduced (Table 2) and the final weights of the visceral adipose tissues were significantly lower than those in the mice fed on the high-fat diet alone. The body weight reduction was proportionally equal to the reduction in the visceral adipose tissue weight after 10 weeks. The weights of organs and adipose tissue of normal and obese mice are shown in Table 3. The high-fat diet led to significant increases in the weights of the visceral adipose tissues, kidney, and liver compared to the weights measured in the normal diet group. Extracts with high-fat diet significantly reduced the final 
TABLE 1: Body weight and food intake of mice during the obesity induction period.

\begin{tabular}{|c|c|c|c|c|c|}
\hline Group (g) & $\mathrm{NC}$ & $\mathrm{OC}$ & Group 1 & Group 2 & Group 3 \\
\hline \multicolumn{6}{|c|}{ Body weight } \\
\hline w0 & $23 \pm 0.7$ & $23.2 \pm 1.2$ & $22.5 \pm 0.5$ & $23.1 \pm 0.7$ & $23.5 \pm 0.3^{\mathrm{a}}$ \\
\hline w10 & $30.7 \pm 1.5$ & $40.5 \pm 1.3^{\mathrm{a}}$ & $42.3 \pm 4.8^{\mathrm{a}}$ & $41.5 \pm 2.8^{\mathrm{a}}$ & $43.6 \pm 3.3$ \\
\hline \multicolumn{6}{|c|}{ Body weight gain } \\
\hline w0-10 & $7.72 \pm 2.5$ & $17.52 \pm 3.5^{\mathrm{a}}$ & $19.38 \pm 5.4^{\mathrm{a}}$ & $18.5 \pm 2.8^{\mathrm{a}}$ & $20.6 \pm 2.2^{\mathrm{a}}$ \\
\hline \multicolumn{6}{|c|}{ Food intake (g/rat/day) } \\
\hline w0-10 & $8.9 \pm 1.2$ & $10.1 \pm 2.1^{\mathrm{a}}$ & $11.3 \pm 1.5^{\mathrm{a}}$ & $11.6 \pm 0.8^{\mathrm{a}}$ & $12.2 \pm 2.3^{\mathrm{a}}$ \\
\hline
\end{tabular}

Each value represents mean \pm S.E.M. ( $n=10$ animals in each group). Values for a given parameter in a row that do not share a common superscript are significantly different at ${ }^{\mathrm{a}} P<0.05$. W (week); NC: normal control with low-fat diet; OC: obese control with high-fat diet.

TABLE 2: Effect of $P$. canariensis extracts on changes in body weight in mice.

\begin{tabular}{|c|c|c|c|c|c|}
\hline \multirow{2}{*}{ Group } & \multirow{2}{*}{ Treatment } & \multicolumn{4}{|c|}{ Body weight changes } \\
\hline & & 0 weeks & 4 weeks & 6 weeks & 10 weeks \\
\hline I & NC & $30.7 \pm 1.5$ & $30.8 \pm 0.5$ & $31.0 \pm 1.2$ & $31.2 \pm 2.4$ \\
\hline II & $\mathrm{OC}$ & $40.5 \pm 1.3$ & $41.0 \pm 3.5$ & $41.5 \pm 5.0$ & $42.0 \pm 5.4$ \\
\hline III & $\mathrm{OC}+\mathrm{AL}-\mathrm{H}$ & $42.3 \pm 4.8$ & $40.7 \pm 2.1$ & $38.5 \pm 3.4^{\mathrm{a}}$ & $37.7 \pm 4.1^{\mathrm{a}}$ \\
\hline IV & $\mathrm{OC}+\mathrm{AL}-\mathrm{C}$ & $41.5 \pm 2.8$ & $37.9 \pm 3.1$ & $36.8 \pm 2.5^{\mathrm{a}}$ & $35.2 \pm 3.0^{\mathrm{a}}$ \\
\hline $\mathrm{V}$ & $\mathrm{OC}+\mathrm{AL}-\mathrm{M}$ & $43.6 \pm 3.3^{\mathrm{a}}$ & $39.1 \pm 2.9$ & $37.7 \pm 4.5^{\mathrm{a}}$ & $36.4 \pm 1.5^{\mathrm{a}}$ \\
\hline
\end{tabular}

Each value represents mean \pm S.E.M. $\left(n=10\right.$ animals in each group) ${ }^{a} P<0.05$. NC: normal control with low-fat diet and OC: obese control with high-fat diet. Hexane extract (AL-H), chloroform extract (AL-C), and methanol extract (AL-M) from P. canariensis.

TABLE 3: Effect of different extracts of $P$. canariensis on the weights of organs and adipose tissue of normal and obese mice.

\begin{tabular}{|c|c|c|c|c|c|}
\hline \multirow{2}{*}{ Group } & \multirow[b]{2}{*}{ LFD } & \multirow[b]{2}{*}{ HFD } & \multicolumn{3}{|c|}{ HFD + } \\
\hline & & & AL-H & $\mathrm{AL}-\mathrm{C}$ & AL-M \\
\hline Liver (g/100 g body weight) & $5.58 \pm 0.95$ & $5.69 \pm 0.45$ & $5.56 \pm 1.06$ & $5.57 \pm 1.23$ & $5.54 \pm 1.30$ \\
\hline Kidney (g/100 g body weight) & $1.61 \pm 0.02$ & $1.47 \pm 0.08$ & $1.51 \pm 0.05$ & $1.53 \pm 0.04$ & $1.50 \pm 0.02$ \\
\hline Plasma total $\left(\mathrm{U} \mathrm{mL}^{-1}\right)$ & $1.13 \pm 0.07$ & $1.58 \pm 0.05$ & $1.16 \pm 0.03^{\mathrm{a}}$ & $1.14 \pm 0.06^{\mathrm{a}}$ & $1.19 \pm 0.04^{\mathrm{a}}$ \\
\hline $\operatorname{Muscle}\left(\mathrm{U} \mathrm{mg}^{-1}\right)$ & $1.11 \pm 0.01$ & $0.76 \pm 0.07$ & $0.96 \pm 0.04^{\mathrm{a}}$ & $0.99 \pm 0.05^{\mathrm{a}}$ & $0.98 \pm 0.08^{\mathrm{a}}$ \\
\hline $\operatorname{VAT}\left(\mathrm{U} \mathrm{mg}^{-1}\right)$ & $0.76 \pm 0.07$ & $1.21 \pm 0.06$ & $0.78 \pm 0.09^{\mathrm{a}}$ & $0.75 \pm 0.08^{\mathrm{a}}$ & $0.77 \pm 0.03^{\mathrm{a}}$ \\
\hline SAT $\left(\mathrm{U} \mathrm{mg}^{-1}\right)$ & $1.12 \pm 0.05$ & $1.32 \pm 0.02$ & $1.17 \pm 0.09^{\mathrm{a}}$ & $1.14 \pm 0.06^{\mathrm{a}}$ & $1.15 \pm 0.01^{\mathrm{a}}$ \\
\hline
\end{tabular}

Each value represents mean \pm S.E.M. ( $n=10$ animals in each group). LFD: low-fat diet; HFD: high-fat diet; hexane extract (AL-H), chloroform extract (AL-C), and methanol extract (AL-M) from P. canariensis; Postheparin plasma (plasma); hind limb muscle (muscle); visceral adipose tissue; the visible mesenteric fat and fat around the liver, kidney, and spleen (VAT); subcutaneous adipose tissue subcutaneous adipose tissue in the abdomen $\left(\right.$ SAT). ${ }^{\mathrm{a}} P<0.05$ versus control group.

weights of the liver and adipose tissues compared to the levels measured in the animals fed on the high-fat diet alone. The kidney weight was decreased in the HFD group compared with the LFD group. The HDF caused the elevation of plasma total. The moderate doses $(200 \mathrm{mg} / \mathrm{kg}$ per day) of hexane, chloroform, and methanol extracts significantly decreased the level of plasma total $(26 \%, 28 \%$, and $25 \%$ resp.). The VAT and liver weight were significantly lower with extracts groups compared with the control mice at 10 weeks, while in SAT weight between the groups of mice at the end point of the experimental period showed decrease of $11 \%, 14 \%$, and $13 \%$, respectively (Table 3 ).

3.3. Effect of the P. canariensis Extracts on Lipid Profile and Hepatic Lipid. Table 4 shows the plasma cholesterol, level of the experimental animals. Significant increase in the levels of plasma cholesterol was observed in the HFD fed groups for the initial ten weeks. After treatment the plasma cholesterol was significantly decreased in the treatment to 39\% (AL$\mathrm{H})$ as compared to cholesterol level in HFD-fed control groups. The HFD-fed rats receiving 10 weeks of treatment with $P$. canariensis extracts $(200 \mathrm{mg} / \mathrm{kg}$ per day) also showed significantly lower values of plasma TG 35\%, 44\%, and 32\% for hexane, chloroform, and methanol extract, respectively, compared with the vehicle-treated counterparts (Table 4). The moderate doses $(200 \mathrm{mg} / \mathrm{kg}$ per day) of $P$. canariensis extracts of hexane, chloroform, and methanol increased the level of plasma HDL (24\%, 27\%, and 21\% increase resp.). The HFD caused elevation of hepatic TC and TG. All $P$. canariensis extracts decreased the level of hepatic TC (25\%, $29 \%$, and $24 \%$ reduction, resp.). The moderate doses of $P$. canariensis extracts significantly reduced the TG hepatic $(35 \%, 37 \%$, and $33 \%$ reduction, resp.). On the one hand, 
there were no significant differences in lipid profile and hepatic lipid in all groups. The hepatic tryglicerides levels in the normal group, high-fat diet group, and high-fat $+P$. canariensis extracts (AL-H, AL-C, AL-M) diet group were $86.2 \pm 6.7,84.5 \pm 5.8$, and $87.3 \pm 2.0 \mathrm{mg} / \mathrm{g}$ liver, respectively. In addition, plasma tryglicerides levels tended to be reduced in the high-fat diet group because of a decrease in triacylglycerol secretion from the liver.

3.4. Lipid Peroxidation and Protein Estimation. MDA, which is the final product of lipid peroxidation, was determined spectrophotometrically. HFD increased the MDA level in plasma when compared with that of the normal group. HFD group treatment with AL extracts showed a significant reduction in MDA levels (Table 4).

3.5. Effect of $P$. canariensis Extracts on the Activities of Hepatic Enzymes. As shown in Table 4, AL-H exhibits a hepatoprotective effect in vivo, indicated with reduced ALP, SGOT, and SGPT levels. It was found that mice fed with high-fat diet alone developed a high degree of steatosis. The effect of increased liver enzymes levels and the formation of steatosis in the high-fat diet-fed group correlates with an increase of liver weight (Table 3). The administration of AL$\mathrm{H}$ resulted in the prevention of hepatic fatty deposition in hepatocytes at dose of $400 \mathrm{mg} / \mathrm{kg}$.

3.6. Effect on Diabetic Mice of the Hexane Extract from P. canariensis on Body Weight and Food and Water Intake. During the study period of 4 weeks, body weight and food and water intake of each mouse were recorded daily but data is presented only at day 0 and the end of the experimentation period (Table 5). The body weight, liver and kidney weights of mice from STZ control group (after 15 days) were significantly $(P<0.001)$ decreased when compared with normal control group. The extract at dose of $400 \mathrm{mg} / \mathrm{kg}$ b.w. significantly $(P<0.001)$ maintained the body weight and liver and kidney weights toward normal as compared with STZ control.

3.7. Serum Biochemical Parameters. Biochemical parameters like SGOT, SGPT, SALP, and proteins in the STZ control group were significantly $(P<0.001)$ elevated as compared with the normal control group. Treatment with AL at the dose of $400 \mathrm{mg} / \mathrm{kg}$ b.w. significantly $(P<0.001)$ brought the SGOT, SGPT, SALP, and serum protein toward the normal values. The total protein was found to be significantly $(P<$ 0.001) decreased in the STZ controls groups as compared with the normal control group indicating a lower capacity for protein synthesis in the livers of the diabetic animals; the administration of hexane extract in types SD and MD diabetic animals significantly $(P<0.001)$ prevented the loss of total protein content as compared with the STZ control group (Table 6).

3.8. Effect of P. canariensis Extracts on the Serum Lipid Profile and Hepatic and Renal TBARS. There was a significant elevation in serum triglycerides and total cholesterol and TBARS levels in the liver and kidney of diabetic mice while
LDL-cholesterol decreased (Table 7). Daily administration of $P$. canariensis extracts at a dose of $400 \mathrm{mg} / \mathrm{kg}$ to diabetic mice for 30 days significantly reduced in severe and mild diabetes total cholesterol and triglycerides by $33 \%, 45 \%$ and $45 \%, 37 \%$, respectively. TBARS level in diabetic mice also decreased after treatment with the extract, $22.0 \%$ and $37 \%$ in liver and $28 \%$ and $29 \%$ in kidney. LDL-cholesterol on the other hand upon treatment also got a decrease. The results also demonstrate a significant control of serum lipid profiles in the $P$. canariensis hexane extract treated diabetic mice, with responses comparable with those of the standard drug.

3.9. Effect of $P$. canariensis Extracts on the Fasting Blood Glucose Levels in Normal and Diabetic Mice. The oral administration of AL at doses of $100,200 \mathrm{mg} / \mathrm{kg}$, and $400 \mathrm{mg} / \mathrm{kg}$ produced a significant hypoglycaemic effect in normal fasting mice after $4 \mathrm{~h}$. The most pronounced effect of AL was observed after $6 \mathrm{~h}$ (Table 8 ). The dose at $200 \mathrm{mg} / \mathrm{kg}$ reduced the blood glucose level of the normal fasting mice from an initial mean value of 102.48 at the initial time $(0 \mathrm{~h})$ to a mean value of $50.76(50 \%)$ at the end of the 6 hrs. Whereas, in the group that received $400 \mathrm{mg} / \mathrm{kg}$ body weight of the extract, there was a significant reduction in blood glucose level in fasting normal mice (60\%) after $6 \mathrm{~h}(P<0.05)$. Oral treatment with glibenclamide $(4 \mathrm{mg} / \mathrm{kg})$ caused a light reduction in blood glucose levels. Reduction in the blood glucose level caused by AL-H at all doses is higher than that of standard drug, glibenclamide.

3.10. Effect of on Fasting Blood Glucose Levels in STZInduced Severe Diabetic Mice and STZ-Nicotinamide-Induced Mildly Diabetic Mice. The antihyperglycemic effect of AL$\mathrm{H}$ on the fasting blood glucose levels in STZ-induced SD and STZ-nicotinamide-induced MD diabetic mice is shown in Table 9. In addition, AL-H given at same concentrations produced significant antihyperglycemic effects $(P<0.005)$ on streptozotocin-induced severe and mildly diabetic mice after 2 weeks of treatment. Treatment of diabetic mice with glibenclamide $(4 \mathrm{mg} / \mathrm{kg}$ ) produced a significant fall in blood glucose after 4 weeks (68\%). Hexane extract (AL-H) at $400 \mathrm{mg} / \mathrm{kg}$ dose gradually decreased blood glucose level 4 weeks after administration (54\% and 52\%, resp.). In diabetes mildly, continued glucose lowering effect at the end of the study when compared to diabetic control.

3.11. Oral Glucose Tolerance Test. The effect of AL-H on glucose tolerance was determined after the 30 days of treatment. Postprandial blood glucose levels in mice show a significant change after glucose loading, increasing rapidly in all groups of diabetic mice within the first $30 \mathrm{~min}$ and remaining high over the next $120 \mathrm{~min}$ in diabetic control mice. Table 11 shows the changes in the levels of blood glucose in normal, diabetic control, and experimental groups after oral administration of glucose $(2 \mathrm{~g} / \mathrm{kg})$. Oral treatment $(400 \mathrm{mg} / \mathrm{kg})$ in diabetic control rats with the hexane extract of seeds of $P$. canariensis produced a significant $(P<0.05)$ reduction of glucose in blood at $120 \mathrm{~min}$, showing a $45 \%$ and $47 \%$ decrease of glucose in blood in severe and mild diabetes, respectively, 
TABle 4: Effect of different extracts of $P$. canariensis on the lipid profiles and hepatic enzymes of normal and obese mice.

\begin{tabular}{|c|c|c|c|c|c|}
\hline Group & NC & $\mathrm{OC}$ & $\mathrm{OC}+\mathrm{AL}-\mathrm{H}$ & $\mathrm{OC}+\mathrm{AL}-\mathrm{C}$ & $\mathrm{OC}+\mathrm{AL}-\mathrm{M}$ \\
\hline \multicolumn{6}{|l|}{ Serum plasma } \\
\hline Total cholesterol (mg/dL) & $70.3 \pm 1.3$ & $120.5 \pm 5.4$ & $74.0 \pm 3.2^{\mathrm{a}}$ & $71.4 \pm 4.2^{\mathrm{a}}$ & $72.6 \pm 2.5^{\mathrm{a}}$ \\
\hline $\mathrm{HDL}(\mathrm{mg} / \mathrm{dL})$ & $43 \pm 2.0$ & $32.0 \pm 1.6$ & $39.7 \pm 2.2^{\mathrm{a}}$ & $40.7 \pm 3.2^{\mathrm{a}}$ & $38.9 \pm 0.6^{\mathrm{a}}$ \\
\hline Triglycerides (mg/dL) & $82.4 \pm 3.1$ & $115.8 \pm 5.3$ & $86.2 \pm 6.7^{\mathrm{a}}$ & $84.5 \pm 5.8^{\mathrm{a}}$ & $87.3 \pm 2.0^{\mathrm{a}}$ \\
\hline MDA (nmol MDA/mg protein) & $0.05 \pm 0.00$ & $0.08 \pm 0.00$ & $0.06 \pm 0.00^{\mathrm{a}}$ & $0.05 \pm 0.00^{\mathrm{a}}$ & $0.06 \pm 0.00^{\mathrm{a}}$ \\
\hline \multicolumn{6}{|l|}{ Hepatic lipids } \\
\hline Cholesterol ( $\mu \mathrm{mol} / \mathrm{g}$ liver$)$ & $18.2 \pm 4.3$ & $35.6 \pm 5.3$ & $26.7 \pm 6.1^{\mathrm{a}}$ & $25.2 \pm 7.5^{\mathrm{a}}$ & $27.0 \pm 7.7^{\mathrm{a}}$ \\
\hline Triglyceride ( $\mu \mathrm{mol} / \mathrm{g}$ liver $)$ & $13.8 \pm 3.4$ & $26.9 \pm 4.8$ & $17.4 \pm 3.3^{\mathrm{a}}$ & $16.8 \pm 5.2^{\mathrm{a}}$ & $18.0 \pm 5.0^{\mathrm{a}}$ \\
\hline \multicolumn{6}{|l|}{ Hepatic enzymes } \\
\hline $\operatorname{ALP}(\mathrm{U} / \mathrm{mL})$ & $0.52 \pm 0.07$ & $0.63 \pm 0.04$ & $0.57 \pm 0.04$ & $0.54 \pm 0.08$ & $0.59 \pm 0.01$ \\
\hline SGOT $(\mathrm{U} / \mathrm{mL})$ & $1.79 \pm 0.08$ & $2.01 \pm 0.05$ & $1.86 \pm 0.03$ & $1.84 \pm 0.05$ & $10.88 \pm 0.02$ \\
\hline SGPT $(\mathrm{U} / \mathrm{mL})$ & $0.58 \pm 0.06$ & $0.72 \pm 0.02$ & $0.65 \pm 0.02$ & $0.64 \pm 0.08$ & $0.68 \pm 0.06$ \\
\hline
\end{tabular}

Each value represents mean \pm S.E.M. $\left(n=10\right.$ animals in each group) ${ }^{\mathrm{a}} \mathrm{P}<0.05$ versus obese control. Hexane extract (AL-H), chloroform extract $(\mathrm{AL}-\mathrm{C})$, and methanol extract (AL-M) from P. canariensis.

TABLE 5: Effect of hexane extract of $P$. canariensis on the body weight, organ weight and food and water intake of normal and diabetic mice.

\begin{tabular}{|c|c|c|c|c|c|c|c|}
\hline \multirow{2}{*}{ Group (mg/kg) } & \multicolumn{3}{|c|}{ Body weight (g) } & \multicolumn{2}{|c|}{ Intake $(\mathrm{g} / \mathrm{d})$} & \multicolumn{2}{|c|}{ Final (g) } \\
\hline & Initial & Final & Gain & Food & Water & Liver weight & Kidney weight \\
\hline Nondiabetic & $25.8 \pm 4.8$ & $32.4 \pm 5.1^{\mathrm{a}}$ & $\begin{array}{c}6.6 \pm 2.2^{\mathrm{a}} \\
(25)\end{array}$ & $29.3 \pm 3.2^{\mathrm{a}}$ & $34.1 \pm 6.3^{\mathrm{a}}$ & $6.76 \pm 2.7^{\mathrm{a}}$ & $1.31 \pm 0.5^{\mathrm{a}}$ \\
\hline SD & $28.0 \pm 6.2$ & $30.0 \pm 6.3^{c}$ & $\begin{array}{c}2.0 \pm 0.6^{c} \\
(7)\end{array}$ & $39.2 \pm 5.8^{\mathrm{c}}$ & $189.5 \pm 9.6^{c}$ & $3.48 \pm 1.3^{\mathrm{c}}$ & $0.81 \pm 0.05^{\mathrm{c}}$ \\
\hline $\mathrm{MD}$ & $25.2 \pm 5.4$ & $27.4 \pm 6.0^{\mathrm{c}}$ & $\begin{array}{c}2.2 \pm 0.7^{\mathrm{c}} \\
(8)\end{array}$ & $37.6 \pm 6.1^{\mathrm{c}}$ & $180.7 \pm 10.4^{\mathrm{c}}$ & $3.40 \pm 1.5^{c}$ & $0.82 \pm 0.04^{\mathrm{c}}$ \\
\hline $\mathrm{SD}+\mathrm{AL}-\mathrm{H}$ & $26.6 \pm 7.4$ & $30.7 \pm 8.2^{\mathrm{b}}$ & $\begin{array}{c}4.1 \pm 1.6^{\mathrm{b}} \\
(15)\end{array}$ & $32.2 \pm 2.9^{\mathrm{b}}$ & $139.5 \pm 5.2^{\mathrm{b}}$ & $5.10 \pm 2.8^{\mathrm{b}}$ & $0.98 \pm 0.02^{\mathrm{b}}$ \\
\hline $\mathrm{MD}+\mathrm{AL}-\mathrm{H}$ & $24.9 \pm 7.4$ & $28.3 \pm 7.4^{\mathrm{c}}$ & $\begin{array}{c}3.4 \pm 0.4^{\mathrm{b}} \\
(18)\end{array}$ & $31.4 \pm 7.5^{\mathrm{b}}$ & $123.0 \pm 5.1^{\mathrm{b}}$ & $5.89 \pm 1.9^{\mathrm{b}}$ & $1.22 \pm 0.05^{\mathrm{b}}$ \\
\hline $\mathrm{SD}+\mathrm{GB}$ & $24.5 \pm 6.2$ & $28.2 \pm 5.8^{\mathrm{b}}$ & $\begin{array}{c}48.7 \pm 4.7^{\mathrm{b}} \\
(20)\end{array}$ & $28.2 \pm 2.5^{\mathrm{b}}$ & $113.3 \pm 5.0^{\mathrm{b}}$ & $6.10 \pm 3.7^{\mathrm{b}}$ & $1.29 \pm 0.7^{\mathrm{b}}$ \\
\hline
\end{tabular}

Each value represents mean \pm S.E.M. $(n=10)$, ANOVA followed by multiple two-tail " $t$ " test. In each vertical column, mean with different superscripts (a, b, and c) differed from " $t$ " each other significantly, $P<0.05$. () indicates \%.

compared with diabetic mice (Table 10). These results reflect the efficiency of the extract to control elevated blood glucose levels.

3.12. Effect on Hepatic Glucose Regulation Enzyme Activities and Skeletal Glycogen Content. Table 11 shows the effect of the hexane extract on G6Pase, GK, and HK activity and glycogen content of liver and skeletal muscle. Administration of AL-Hat $400 \mathrm{mg} / \mathrm{kg}$ body weight increased the content of hepatic glycogen, GK, and HK in diabetic mice while G6Pase decreased. Our results showed that the hexokinase activity tended to be reversed to normal values, while normal mice did not exhibit any significant alteration.

3.13. Effect of $P$. canariensis Extracts on the Antioxidant Enzyme Activities of the Liver, Kidney, and Pancreas. The antioxidant effect of the $P$. canariensis extract over tissue oxidative markers was studied here (Table 12). Diabetic mice showed a significant reduction in SOD, CAT, GSH, and GPx in hepatic and renal tissues. Low levels of SOD, CAT, GSH, and GPx in diabetic mice were reverted to near normal values after treatment with hexane extract. The readings obtained from the treated groups were comparable to that of the standard drug glibenclamide. Administration of $P$. canariensis to diabetic mice showed restoring of liver and kidney activities as reflected by these parameters. Hyperglycemia induced oxidative stress may also cause liver cell damage. Lower activity of antioxidant enzymes such as SOD, GSH, GPx, and CAT and increased rate of glycation oxidation lead to diabetes complications. Levels of these enzymes were back to near normal values after treatment with $P$. canariensis extract.

3.14. Effect of $A L$ on Serum Insulin Level and Pancreatic Insulin Content. In streptozotocin-induced diabetic mice insulin in serum and in pancreas decrease markedly, as low as $1.5 \mu \mathrm{IU} / \mathrm{mL}$ in the STZ untreated mice compared with the nondiabetic control group $(3.6 \mu \mathrm{IU} / \mathrm{mL})$. Treatment with glibenclamide for 30 days restored insulin levels. After three weeks of administration of the $P$. canariensis 
TABLE 6: Effect of hexane extract of P. canariensis on some serum biochemical parameters of normal and diabetic mice.

\begin{tabular}{lcccc}
\hline Group & & IU/I & ALP & g/dL \\
& SGOT & SGPT & $170.3 \pm 10.4$ & $7.9 \pm 2.1$ \\
Nondiabetic control & $20.9 \pm 3.2$ & $24.3 \pm 5.8$ & $245.1 \pm 11.6^{\mathrm{a}}$ & $4.3 \pm 1.5^{\mathrm{a}}$ \\
SD control & $39.2 \pm 8.9^{\mathrm{a}}$ & $42.3 \pm 7.1^{\mathrm{a}}$ & $239.8 \pm 9.7^{\mathrm{a}}$ & $4.0 \pm 1.2^{\mathrm{a}}$ \\
MD control & $38.7 \pm 7.7^{\mathrm{a}}$ & $42.9 \pm 8.6^{\mathrm{a}}$ & $209.2 \pm 10.7^{\mathrm{b}}$ & $6.5 \pm 1.4^{\mathrm{b}}$ \\
SD + AL-H & $27.3 \pm 6.2^{\mathrm{b}}$ & $34.6 \pm 5.5^{\mathrm{b}}$ & $195.8 \pm 9.1^{\mathrm{b}}$ & $6.7 \pm 2.4^{\mathrm{b}}$ \\
MD +AL-H & $24.0 \pm 4.8^{\mathrm{b}}$ & $28.6 \pm 6.3^{\mathrm{b}}$ & $192.1 \pm 11.8^{\mathrm{b}}$ & $7.2 \pm 3.8^{\mathrm{b}}$ \\
SD + GB & $23.1 \pm 8.0^{\mathrm{b}}$ & $25.1 \pm 5.7^{\mathrm{b}}$ & \\
\hline
\end{tabular}

Values are expressed as mean $\pm \operatorname{SEM}(n=6)^{\mathrm{a}} P<0.001$ compared with normal control and ${ }^{\mathrm{b}} P<0.001$ compared with STZ control group. ALP: alkaline phosphatase; SGOT: serum glutamate oxaloacetate transaminase; SGPT: serum glutamate; GB: glibenclamide.

TABLE 7: Effect of hexane extract of $P$. canariensis on lipid profile and malondialdehyde concentration in normal and diabetic mice.

\begin{tabular}{|c|c|c|c|c|c|c|}
\hline \multirow{3}{*}{$\begin{array}{l}\text { Group } \\
(\mathrm{mg} / \mathrm{kg})\end{array}$} & \multicolumn{6}{|c|}{ Mean concentration $(\mathrm{mg} / \mathrm{g}) \pm \mathrm{SEM}$} \\
\hline & \multirow{2}{*}{$\begin{array}{l}\text { Triglycerides } \\
\quad(\mathrm{mg} / \mathrm{dL})\end{array}$} & \multirow{2}{*}{$\begin{array}{l}\text { Total cholesterol } \\
(\mathrm{mg} / \mathrm{dL})\end{array}$} & \multirow{2}{*}{$\begin{array}{l}\text { HDL-cholesterol } \\
\text { (mg/dL) }\end{array}$} & \multirow{2}{*}{$\begin{array}{l}\text { LDL-cholesterol } \\
\qquad(\mathrm{mg} / \mathrm{dL})\end{array}$} & \multicolumn{2}{|c|}{ TBARS $(\mu \mathrm{M} / \mathrm{g})$} \\
\hline & & & & & Liver & Kidney \\
\hline Nondiabetic control & $93.44 \pm 6.12$ & $130.71 \pm 4.26$ & $70.42 \pm 4.32$ & $41.34 \pm 6.12$ & $0.99 \pm 0.003$ & $1.6 \pm 0.08$ \\
\hline SD control & $189.86 \pm 8.63^{\mathrm{a}}$ & $247.23 \pm 1.67^{\mathrm{a}}$ & $35.36 \pm 1.57^{\mathrm{a}}$ & $72.85 \pm 5.72^{\mathrm{a}}$ & $1.61 \pm 0.07^{\mathrm{a}}$ & $2.5 \pm 0.07^{\mathrm{a}}$ \\
\hline MD control & $173.41 \pm 5.34^{\mathrm{a}}$ & $203.56 \pm 7.53^{\mathrm{a}}$ & $39.72 \pm 4.82^{\mathrm{a}}$ & $68.21 \pm 8.33^{\mathrm{a}}$ & $1.60 \pm 0.06^{\mathrm{a}}$ & $2.4 \pm 0.04^{\mathrm{a}}$ \\
\hline $\mathrm{SD}+\mathrm{AL}$ & $127.25 \pm 4.12^{\mathrm{b}}$ & $135.36 \pm 2.98^{\mathrm{b}}$ & $52.40 \pm 2.80^{\mathrm{ab}}$ & $61.51 \pm 3.70^{\mathrm{a}}$ & $1.26 \pm 0.03$ & $1.8 \pm 0.03^{\mathrm{b}}$ \\
\hline $\mathrm{MD}+\mathrm{AL}$ & $93.78 \pm 6.03^{\mathrm{b}}$ & $127.26 \pm 3.17^{\mathrm{b}}$ & $60.34 \pm 3.56^{\mathrm{ab}}$ & $53.73 \pm 4.21^{\mathrm{b}}$ & $1.01 \pm 0.06^{\mathrm{b}}$ & $1.7 \pm 0.05^{\mathrm{b}}$ \\
\hline $\mathrm{SD}+\mathrm{GB}$ & $89 \pm 5.28^{b}$ & $126.32 \pm 2.65^{\mathrm{b}}$ & $54.39 \pm 2.75^{\mathrm{ab}}$ & $46.94 \pm 4.32^{\mathrm{b}}$ & $0.93 \pm 0.09^{\mathrm{b}}$ & $1.7 \pm 0.04^{\mathrm{b}}$ \\
\hline
\end{tabular}

All values are expressed as mean \pm SEM, $n=10 .{ }^{\mathrm{a}} \mathrm{P}<0.05$ when compared to normal control group, ${ }^{\mathrm{b}} \mathrm{P}<0.01$ when compared to diabetic control group, where the significance was performed by one-way ANOVA followed by post hoc Dunnett's test.

hexane extract there was also a notorious elevation in serum insulin and pancreatic insulin levels. This is shown in Table 13.

\section{Discussion}

Obesity induction via dietary means in animal models has been considered as the most popular reference among researchers due to its high similarity of mimicking the usual route of obesity occurrence in humans. It is generally known that high-fat diet is one of the major factors causing obesity and that the long-term intake of high-fat diet evokes a significant increase in abdominal fat weight in mammals [33]. The present study, which represents the first report on the antiobesity and lipid-lowering effects of seeds of $P$. canariensis in obese animals, has shown that there was a significant difference in the body weights between the high-fat and normal diet groups; no significant difference in the daily food intake between groups was observed. The high-fat diet groups continuously consumed similar quantities of food, regardless of the higher calories content in the diet. As a result, the caloric intake was raised in the high-fat diet group compared to the normal group counterpart. The supplementation of obese rats with $\mathrm{AL}-\mathrm{H}$ at $400 \mathrm{mg} / \mathrm{kg}$ conversely causes a remarkable reduction of body weights compared to the untreated obese group. The findings demonstrated that $\mathrm{AL}-\mathrm{H}$ is capable of preventing body weight gain and showed a significant reduction in their body weight after 4 weeks of treatment. $\mathrm{AL}-\mathrm{H}$ has shown that oral administration of $P$. canariensis modulates lipid homeostasis in the development of HFDinduced obesity. In this study, feeding a hyperlipidaemic diet containing $45 \%$ energy from fat for 10 weeks caused obesity, hyperlipidaemia, and hyperglycaemia in mice [34], However, P. canariensis supplementation not only suppressed excessive gains of weight in body, liver, kidney, visceral adipose tissue (VAT) and subcutaneous abdominal adipose tissue (SAT), by affecting adipose tissue growth through modulation of HFD-induced hypertrophy of adipocytes, but also reduced serum lipids, which is defined as the main risk for dyslipidaemia [35]. As shown in our data AL-H decreases in the levels of serum and hepatic lipids such as triglycerides, total cholesterol, HDL-cholesterol, and LDL-cholesterol in mice compared to those for mice fed with HFD only, which may possibly be due to suppressed lipid accumulation [36].

The increased MDA level in the untreated obese group clearly demonstrated that high fat consumption was attributed to increased oxidative stress. AL-H supplementation was found to improve the endogenous antioxidant defense system by enhancing the antioxidant enzymes activities in vivo. The groups treated with AL-H showed a significant elevation in their SOD, GPx, GSH, and CAT activities compared to the untreated obese rats. These results are aligned with the reduction of MDA levels, which may be related to the ability of AL-H to suppress lipid peroxidation due to having an increase in the activity of antioxidant enzymes, regardless of the availability of lipid substrates. 
TABle 8: Acute effect of hexane extract of $P$. canariensis on fasting blood glucose level of normal and diabetic mice.

\begin{tabular}{|c|c|c|c|c|c|c|c|}
\hline \multirow{2}{*}{ Group } & \multirow{2}{*}{ Dose $(\mathrm{mg} / \mathrm{kg})$} & \multirow{2}{*}{ At the time of grouping } & \multicolumn{5}{|c|}{ Blood glucose levels (mg/dL) at different time intervals (hours) } \\
\hline & & & $2 \mathrm{~h}$ & $4 \mathrm{~h}$ & $6 \mathrm{~h}$ & $8 \mathrm{~h}$ & $12 \mathrm{~h}$ \\
\hline Nondiabetic control & - & $102.45 \pm 4.56$ & $101.7 \pm 5.95$ & $100.56 \pm 7.89$ & $102.76 \pm 7.42$ & $99.55 \pm 8.90$ & $103.15 \pm 5.76$ \\
\hline \multirow{3}{*}{ Nondiabetic + AL-H } & 100 & $103.61 \pm 7.92$ & $94.23 \pm 6.98^{\mathrm{a}}$ & $84.80 \pm 11.04^{\mathrm{a}}$ & $80.75 \pm 9.48^{\mathrm{a}}$ & $81.59 \pm 8.53^{\mathrm{a}}$ & $94.87 \pm 5.69^{\mathrm{a}}$ \\
\hline & 200 & $102.48 \pm 8.39$ & $89.18 \pm 7.42^{\mathrm{a}}$ & $57.29 \pm 8.59^{\mathrm{a}}$ & $50.76 \pm 6.54^{\mathrm{a}}$ & $54.37 \pm 7.90^{\mathrm{a}}$ & $73.43 \pm 10.01^{\mathrm{a}}$ \\
\hline & 400 & $104.22 \pm 6.47$ & $80.38 \pm 8.46^{\mathrm{a}}$ & $48.10 \pm 4.79^{\mathrm{a}}$ & $41.39 \pm 5.25^{\mathrm{a}}$ & $50.49 \pm 9.12^{\mathrm{a}}$ & $70.35 \pm 6.28^{\mathrm{a}}$ \\
\hline SD control & - & $375.35 \pm 4.87$ & $370.42 \pm 5.90$ & $371.28 \pm 7.41$ & $378.05 \pm 5.16$ & $371.50 \pm 8.47$ & $378.14 \pm 8.46$ \\
\hline MD control & - & $246.82 \pm 7.53$ & $248.67 \pm 8.29$ & $245.78 \pm 9.53$ & $248.71 \pm 6.37$ & $249.73 \pm 8.68$ & $250.04 \pm 7.90$ \\
\hline \multirow{3}{*}{$\mathrm{SD}+\mathrm{AL}-\mathrm{H}$} & 100 & $245.62 \pm 4.81$ & $225.70 \pm 5.80^{\mathrm{a}}$ & $214.52 \pm 11.04^{\mathrm{a}}$ & $190.31 \pm 7.58^{\mathrm{a}}$ & $200.31 \pm 7.58^{\mathrm{a}}$ & $213.31 \pm 7.58^{\mathrm{a}}$ \\
\hline & 200 & $281.43 \pm 3.69$ & $232.61 \pm 5.80^{\mathrm{a}}$ & $221.68 \pm 8.59^{\mathrm{a}}$ & $182.81 \pm 6.85^{\mathrm{a}}$ & $190.02 \pm 8.43^{\mathrm{a}}$ & $229.57 \pm 9.32^{\mathrm{a}}$ \\
\hline & 400 & $274.13 \pm 4.23$ & $212.59 \pm 5.74^{\mathrm{a}}$ & $198.39 \pm 4.81^{\mathrm{a}}$ & $149.67 \pm 8.44^{\mathrm{a}}$ & $159.13 \pm 7.64^{\mathrm{a}}$ & $180.42 \pm 6.27^{\mathrm{a}}$ \\
\hline \multirow{3}{*}{$\mathrm{MD}+\mathrm{AL}-\mathrm{H}$} & 100 & $263.26 \pm 6.76$ & $251.38 \pm 7.56^{\mathrm{a}}$ & $233.42 \pm 10.23^{\mathrm{a}}$ & $221.49 \pm 5.46^{\mathrm{a}}$ & $230.16 \pm 4.68^{a}$ & $241.59 \pm 6.89^{\mathrm{a}}$ \\
\hline & 200 & $249.51 \pm 5.64$ & $235.24 \pm 4.80^{\mathrm{a}}$ & $219.65 \pm 6.49^{\mathrm{a}}$ & $196.08 \pm 7.35^{\mathrm{a}}$ & $199.38 \pm 6.72^{\mathrm{a}}$ & $240.67 \pm 9.47^{\mathrm{a}}$ \\
\hline & 400 & $274.38 \pm 6.98$ & $258.16 \pm 5.39^{\mathrm{a}}$ & $230.47 \pm 9.03^{\mathrm{a}}$ & $186.14 \pm 7.10^{\mathrm{a}}$ & $191.53 \pm 5.37^{\mathrm{a}}$ & $262.54 \pm 8.11^{\mathrm{a}}$ \\
\hline $\mathrm{SD}+\mathrm{GB}$ & 0.5 & $348.89 \pm 5.79$ & $272.68 \pm 6.87^{b}$ & $201.35 \pm 2.59^{\mathrm{b}}$ & $209.43 \pm 2.94^{\mathrm{b}}$ & $219.60 \pm 1.98^{b}$ & $266.29 \pm 2.83^{b}$ \\
\hline
\end{tabular}

Each of the values represents mean $\pm \mathrm{SD}(n=6) .{ }^{\mathrm{a}} \mathrm{P}<0.05$ compared to normal group (ANOVA) followed by Dunnett's test. ${ }^{\mathrm{b}} \mathrm{P}<0.05$ compared to diabetic group (ANOVA) followed by Dunnett's test. Glibenclamide (GB).

TABLE 9: Effect of hexane extract of $P$. canariensis on blood glucose level of normal and diabetic mice after 30-day treatment.

\begin{tabular}{|c|c|c|c|c|c|}
\hline \multirow{2}{*}{ Group (mg/kg) } & \multicolumn{5}{|c|}{ Fasting blood glucose level (mg/dL) } \\
\hline & 0 & 1 & 2 & 3 & 4 \\
\hline No-diabetic control & $100.1 \pm 4.7$ & $101.6 \pm 8.5^{\mathrm{a}}$ & $105.4 \pm 7.4^{\mathrm{a}}$ & $107.5 \pm 9.9^{\mathrm{a}}$ & $103.3 \pm 6.8^{\mathrm{a}}$ \\
\hline SD control & $323.7 \pm 6.7$ & $327.6 \pm 9.5^{\mathrm{b}}$ & $341.2 \pm 6.1^{\mathrm{b}}$ & $401.3 \pm 7.6^{\mathrm{b}}$ & $411.4 \pm 15.9^{\mathrm{b}}$ \\
\hline MD control & $268.5 \pm 17.7$ & $277.3 \pm 19.2^{\mathrm{b}}$ & $297.5 \pm 9.4^{\mathrm{b}}$ & $320.6 \pm 17.4^{\mathrm{b}}$ & $334.6 \pm 18.2^{\mathrm{b}}$ \\
\hline $\mathrm{SD}+\mathrm{AL}$ & $356.2 \pm 14.2$ & $\begin{array}{c}313.9 \pm 12.2^{c} \\
(12)\end{array}$ & $\begin{array}{c}190.5 \pm 17.1^{c} \\
(46)\end{array}$ & $\begin{array}{c}170.3 \pm 15.7^{c} \\
(52)\end{array}$ & $\begin{array}{c}161.8 \pm 14.6^{\mathrm{c}} \\
(54)\end{array}$ \\
\hline $\mathrm{MD}+\mathrm{AL}$ & $239.4 \pm 13.7$ & $\begin{array}{c}196.5 \pm 21.3^{c} \\
(18)\end{array}$ & $\begin{array}{c}132.3 \pm 20.6^{c} \\
(45)\end{array}$ & $\begin{array}{c}124.7 \pm 17.9^{c} \\
(48)\end{array}$ & $\begin{array}{c}114.2 \pm 5.6^{\mathrm{c}} \\
(52)\end{array}$ \\
\hline $\mathrm{SD}+\mathrm{GB}$ & $352.6 \pm 6.6$ & $\begin{array}{c}270.5 \pm 6.9^{c} \\
(14.3)\end{array}$ & $\begin{array}{c}152.7 \pm 9.2^{c} \\
(51)\end{array}$ & $\begin{array}{c}109.4 \pm 5.3^{c} \\
(65)\end{array}$ & $\begin{array}{c}100.2 \pm 2.1^{\mathrm{c}} \\
(68)\end{array}$ \\
\hline
\end{tabular}

Each value represents mean \pm S.E.M. $(n=10)$, ANOVA followed by multiple two-tail " $t$ " test.

In each vertical column, mean with different superscripts (a, b, and c) differ from " $t$ " each other significantly, $<0.05$. Glibenclamide (GB) at doses $5 \mathrm{mg} / \mathrm{kg}$. () $\%$ inhibition.

P. canariensis is a kind of traditional medicine which has long been used to effectively treat obesity and diabetesl by local people. In the present findings, we evaluated the antidiabetic effect of AL-H on SD and MD induced by STZ. Our date clearly showed hypoglycemic activity and glucose tolerance pattern was significantly altered comparable to that of glibenclamide. This activity improved glucose tolerance suggesting a decrease in insulin resistance and helping to maintain blood glucose levels steady which may indicate certain induction of peripheral utilization of glucose.

Streptozotocin is known for its selective pancreatic islet beta cells cytotoxicity and has been widely used to induce diabetes mellitus. Besides alteration in the carbohydrate and lipid metabolism, rats treated with STZ also exhibited reduced total protein and liver glycogen levels, increased liver glucose transfer, and decline in liver glycogen content in STZ diabetic rats [37]. From glucose tolerance test it has been indicated that this extract did not execute the antihyperglycemic effect by modulating the absorption of glucose in the intestine. In glucose loaded rats AL-H inhibited significantly the rise of glycemia. This improved glucose tolerance and also suggests that a decrease in insulin resistance and maintenance of blood glucose levels may indicate induction of increased peripheral utilization of glucose [37].

Furthermore, the attenuating effect of this extract on experimental physiological symptoms of streptozotocininduced severe and mild diabetes has been confirmed here by the study of glucose-6-phosphatase activity in liver, as well as the quantification of glycogen in liver and skeletal muscle, which are very important indicators of diabetes mellitus. In our study, the hexane extract of AL-H seeds had a beneficial effect in terms of peripheral glucose utilization.

Control of hepatic glucose (HGO) may occur through regulation of gluconeogenesis or glycogenolysis. However, the common final pathway of glucose uptake and release involved the phosphorylation and dephosphorylation of glucose via GK and G6Pase, respectively [38]. In this study, 
TABLE 10: Effect of hexane extract of P. canariensis on postprandial blood glucose level of normal and diabetic mice.

\begin{tabular}{lccccc}
\hline \multirow{2}{*}{ Groups $(\mathrm{mg} / \mathrm{kg})$} & \multicolumn{3}{c}{ Blood glucose levels (mg/dL) } \\
& $0 \mathrm{~min}$ & $30 \mathrm{~min}$ & $60 \mathrm{~min}$ & $90 \mathrm{~min}$ & $120 \mathrm{~min}$ \\
\hline Nondiabetic control & $92.34 \pm 1.78$ & $178.78 \pm 3.42$ & $160.12 \pm 2.47$ & $126.42 \pm 2.59$ & $96.58 \pm 4.67$ \\
SD control & $368.78 \pm 3.42$ & $344.16 \pm 7.36^{\mathrm{a}}$ & $409.23 \pm 6.21^{\mathrm{a}}$ & $373.41 \pm 6.71^{\mathrm{a}}$ & $348.53 \pm 13.71^{\mathrm{a}}$ \\
MD control & $274.56 \pm 5.94$ & $352.21 \pm 8.44^{\mathrm{a}}$ & $399.60 \pm 9.68^{\mathrm{a}}$ & $362.31 \pm 8.84^{\mathrm{a}}$ & $332.19 \pm 10.28^{\mathrm{a}}$ \\
SD + AL & $366.19 \pm 14.03$ & $335.38 \pm 8.63^{\mathrm{a}}$ & $255.11 \pm 10.39^{\mathrm{c}}$ & $219.23 \pm 11.36^{\mathrm{c}}$ & $199.08 \pm 9.46^{\mathrm{c}}$ \\
MD + AL & $254.46 \pm 10.21$ & $317.49 \pm 12.39^{\mathrm{a}}$ & $268.49 \pm 9.56^{\mathrm{c}}$ & $213.47 \pm 8.46^{\mathrm{c}}$ & $134.89 \pm 11.83^{\mathrm{c}}$ \\
SD + GB & $265.30 \pm 8.00$ & $315.25 \pm 12.25^{\mathrm{a}}$ & $295.05 \pm 8.4^{\mathrm{c}}$ & $263.11 \pm 6.78^{\mathrm{c}}$ & $167.36 \pm 10.83^{\mathrm{c}}$ \\
\hline
\end{tabular}

Values are expressed as mean $\pm \mathrm{SD}(n=10)$, ${ }^{\text {a }}$ significantly $(P<0.05)$ different from normal rats. ${ }^{\mathrm{b}}$ Significantly $(P<0.05)$ different from diabetic rats. ${ }^{\mathrm{c}}$ Significantly $(P<0.05)$ different from normal and diabetic rats, where the significance was performed by Oneway ANOVA followed by post hoc Dunnett's test. ALH extract $400 \mathrm{mg} / \mathrm{kg}$.

TABLE 11: Effect of hexane extract of $P$. canariensis on hepatic glucose regulation enzyme activities of normal and diabetic mice.

\begin{tabular}{|c|c|c|c|c|c|}
\hline \multirow{2}{*}{ Group } & \multirow{2}{*}{$\begin{array}{c}\text { G6Pase } \\
\text { activity }(\mathrm{mU})\end{array}$} & \multirow{2}{*}{$\begin{array}{c}\text { GK activity } \\
(\mathrm{mU})\end{array}$} & \multicolumn{2}{|c|}{ Glycogen $(\mathrm{mg} / \mathrm{g})$} & \multirow{2}{*}{$\begin{array}{c}\text { HK activity } \\
\text { (U/mg protein) }\end{array}$} \\
\hline & & & Liver & Skeletal muscle & \\
\hline Normal control & $0.40 \pm 0.006$ & $3.38 \pm 0.05$ & $19.64 \pm 2.45$ & $11.74 \pm 4.39$ & $1.69 \pm 0.07$ \\
\hline SD control & $0.71 \pm 0.005^{\mathrm{a}}$ & $1.36 \pm 0.06^{\mathrm{a}}$ & $9.67 \pm 3.12^{\mathrm{a}}$ & $4.89 \pm 1.34^{\mathrm{a}}$ & $1.31 \pm 0.03^{\mathrm{a}}$ \\
\hline MD control & $0.69 \pm 0.002^{\mathrm{a}}$ & $1.27 \pm 0.08^{\mathrm{a}}$ & $10.23 \pm 4.35^{\mathrm{a}}$ & $5.27 \pm 1.56^{\mathrm{a}}$ & $1.29 \pm 0.05^{\mathrm{a}}$ \\
\hline $\mathrm{SD}+\mathrm{AL}-\mathrm{H}$ & $0.53 \pm 0.008^{\mathrm{ab}}$ & $2.8 \pm 0.04^{\mathrm{ab}}$ & ${ }^{\mathrm{d}} 17.53 \pm 5.18^{\mathrm{b}}$ & ${ }^{\mathrm{d}} 9.78 \pm 1.54^{\mathrm{b}}$ & ${ }^{\mathrm{d}} 1.53 \pm 0.09^{\mathrm{ab}}$ \\
\hline $\mathrm{MD}+\mathrm{AL}-\mathrm{H}$ & $0.46 \pm 0.007^{\mathrm{ab}}$ & $3.09 \pm 0.03^{\mathrm{ab}}$ & ${ }^{\mathrm{d}} 18.13 \pm 5.80^{\mathrm{b}}$ & ${ }^{\mathrm{d}} 10.89 \pm 2.41^{\mathrm{b}}$ & ${ }^{\mathrm{d}} 1.59 \pm 0.05^{\mathrm{ab}}$ \\
\hline GB 4 (mg/kg) & $0.39 \pm 0.004^{\mathrm{b}}$ & $3.11 \pm 0.04^{\mathrm{b}}$ & $17.78 \pm 2.30^{\mathrm{b}}$ & $11.01 \pm 1.96^{\mathrm{b}}$ & $1.60 \pm 0.03^{\mathrm{ab}}$ \\
\hline
\end{tabular}

Each value represents mean $\pm \mathrm{SD},(n=10)$; ANOVA followed by multiple two-tail " $t$ " test. In each vertical column, mean with different superscripts (a, b) differed from each other. Significant difference of diabetic control from normal control ${ }^{\mathrm{a}} P<0.001$. Significant difference of treated groups from diabetic control ${ }^{\mathrm{b}} P<0.01,{ }^{\mathrm{c}} \mathrm{P}<0.05,{ }^{\mathrm{d}} \mathrm{P}<0.01$ when compared with glibenclamide $4 \mathrm{mg} / \mathrm{kg}$ treated group.

AL-H caused a marked increase in hepatic glycogen content in STZ-induced diabetic mice, which indicates that mice may decrease HGO by increasing glycogen content. In addition, $P$. canariensis decreased G6Pase activity and increased GK activity in liver, which indicates that this can be an increase in hepatic glucose uptake and decrease in hepatic glucose release. Therefore, this study strongly suggests that $P$. canariensis enhances hypoglycemic activity probably by reducing $\mathrm{HGO}$ via decreasing G6Pase activity and increasing GK activity. One of the key enzymes in the catabolism of glucose is hexokinase, which phosphorylates glucose and converts it into glucose-6-phosphate. The increased activity of hexokinase can promote glycolysis and increase utilization of glucose for energy production [39]. The administration of $P$. canariensis to the diabetic mice increased the activity of hepatic hexokinase causing an increase in glycolysis. The hepatic glycogen was found to be increased in both liver and skeletal muscle in diabetic rats and suggested also a reduction in glycogenolysis and an increase in glycogenesis.

Insulin deficiency is associated with hypercholesterolaemia and hypertriglyceridaemia. STZ-induced diabetes showed increased plasma levels of cholesterol, triglyceride, free fatty acid, and phospholipids. Insulin deficiency or insulin resistance could be responsible for dyslipidaemia because insulin increases fatty acid as well as triglyceride synthesis in adipose tissue and liver. It inhibits lipolysis, partly via dephosphorylation (and hence inactivation) of lipases [40]. Insulin deficiency leads to fall in lipoprotein lipase activity.
In our study, STZ mice showed hypercholesterolaemia and hypertriglyceridaemia and the treatment with AL-H significantly decreased both cholesterol and triglyceride levels. STZ induction of diabetes in mice leads to lipid peroxidation. TBARS are an index of endogenous lipid peroxidation and oxidative stress as an intensified free radical production. TBARS levels in both liver and kidney of diabetic control group were high and were significantly reduced upon administration of the hexane extract. These findings supported the hypothesis that $P$. canariensis improved insulin sensitivity.

We studied the antioxidant effect of the AL-H extract over tissue oxidative markers. Diabetic mice showed a significant reduction in SOD, CAT, GSH, and GPx in hepatic and renal tissues as a result of a persistent oxidative stress. One of the main consequences of chronic hyperglycemia is the enhanced oxidative stress resulting from the imbalance between production and neutralization of reactive oxygen species (ROS), in particular, the diabetes-associated free radical injury, accumulation of lipid peroxidation products, depletion of GSH, decrease in GSH/GSSG ratio, and downregulation of key antioxidant enzymes [40]. Accordingly, we measured a decrease in GSH in the liver of diabetic mice, probably due to a higher demand, following the diabetes-induced oxidative stress. The glutathione system, SOD, GPx, GSH, and CAT comprise the most important endogenous antioxidant defense against ROS-induced damage of the cell membrane. SOD protects tissues from oxygen free radicals by catalyzing the removal of free radical superoxide anion $\mathrm{O}_{2}^{\circ}$; GPx and CAT were shown to be responsible for the detoxification of 
TABLE 12: Effect of hexane extract of $P$. canariensis on antioxidant enzyme activities of normal and diabetic mice.

\begin{tabular}{lcccccc}
\hline Parameters & Normal C & SD C & MD C & SD + AL-H & MD + AL-H & SD + GB \\
\hline SOD-liver & $7.54 \pm 2.19$ & $3.79 \pm 0.82^{\mathrm{a}}$ & $4.05 \pm 1.38^{\mathrm{b}}$ & $5.87 \pm 0.89^{\mathrm{b}}$ & $6.01 \pm 1.05^{\mathrm{b}}$ & $6.80 \pm 0.41^{\mathrm{c}}$ \\
SOD-kidney & $13.82 \pm 3.51$ & $7.35 \pm 1.37^{\mathrm{a}}$ & $8.36 \pm 2.53^{\mathrm{b}}$ & $10.24 \pm 2.63^{\mathrm{b}}$ & $11.47 \pm 3.41^{\mathrm{b}}$ & $13.025 \pm 1.57^{\mathrm{b}}$ \\
SOD-pancreas & $54.52 \pm 5.21$ & $36.47 \pm 3.28^{\mathrm{a}}$ & $35.99 \pm 5.42^{\mathrm{b}}$ & $43.88 \pm 5.39^{\mathrm{b}}$ & $46.90 \pm 5.48^{\mathrm{b}}$ & $50.71 \pm 4.36^{\mathrm{b}}$ \\
CAT-liver & $82.36 \pm 6.17$ & $44.53 \pm 3.13^{\mathrm{a}}$ & $47.32 \pm 7.14^{\mathrm{b}}$ & $64.56 \pm 6.38^{\mathrm{b}}$ & $67.12 \pm 6.74^{\mathrm{b}}$ & $70.26 \pm 2.16^{\mathrm{b}}$ \\
CAT-kidney & $35.61 \pm 2.33$ & $20.76 \pm 1.65^{\mathrm{a}}$ & $22.01 \pm 9.53^{\mathrm{c}}$ & $29.56 \pm 2.81^{\mathrm{c}}$ & $32.07 \pm 2.53^{\mathrm{c}}$ & $34.17 \pm 1.79^{\mathrm{b}}$ \\
CAT-pancreas & $59.32 \pm 5.38$ & $25.56 \pm 4.19^{\mathrm{a}}$ & $23.19 \pm 5.46^{\mathrm{a}}$ & $40.24 \pm 3.67^{\mathrm{a}}$ & $43.79 \pm 5.18^{\mathrm{a}}$ & $47.83 \pm 4.36^{\mathrm{c}}$ \\
GSH-liver & $47.68 \pm 7.12$ & $21.80 \pm 1.97^{\mathrm{a}}$ & $29.15 \pm 6.36^{\mathrm{b}}$ & $36.52 \pm 4.86^{\mathrm{b}}$ & $39.48 \pm 4.36^{\mathrm{b}}$ & $42.38 \pm 2.28^{\mathrm{b}}$ \\
GSH-kidney & $24.45 \pm 3.71$ & $5.79 \pm 2.06^{\mathrm{a}}$ & $7.21 \pm 3.53^{\mathrm{b}}$ & $15.29 \pm 3.83^{\mathrm{b}}$ & $17.20 \pm 3.53^{\mathrm{b}}$ & $19.27 \pm 3.58^{\mathrm{b}}$ \\
GSH-pancreas & $12.48 \pm 3.39$ & $5.19 \pm 0.94^{\mathrm{a}}$ & $7.42 \pm 2.56^{\mathrm{b}}$ & $6.91 \pm 1.80^{\mathrm{b}}$ & $8.47 \pm 1.56^{\mathrm{b}}$ & $10.79 \pm 1.92^{\mathrm{b}}$ \\
GPx-liver & $7.26 \pm 1.59$ & $4.31 \pm 1.30^{\mathrm{a}}$ & $5.39 \pm 2.01^{\mathrm{b}}$ & $5.35 \pm 1.83^{\mathrm{b}}$ & $5.64 \pm 1.87^{\mathrm{b}}$ & $5.92 \pm 1.26^{\mathrm{b}}$ \\
GPx-kidney & $5.92 \pm 1.42$ & $3.53 \pm 0.92^{\mathrm{a}}$ & $3.40 \pm 1.43^{\mathrm{b}}$ & $4.53 \pm 1.34^{\mathrm{b}}$ & $4.60 \pm 1.73^{\mathrm{b}}$ & $4.78 \pm 0.94^{\mathrm{b}}$ \\
GPx-pancreas & $4.64 \pm 1.19$ & $2.32 \pm 0.36^{\mathrm{a}}$ & $3.42 \pm 1.26^{\mathrm{b}}$ & $3.31 \pm 0.61^{\mathrm{b}}$ & $3.70 \pm 1.26^{\mathrm{b}}$ & $3.89 \pm 0.27^{\mathrm{b}}$ \\
\hline
\end{tabular}

All values are expressed as mean \pm SEM, $n=6$ values. ${ }^{a} P<0.01$ when compared to normal control group; ${ }^{\mathrm{b}} P<0.01,{ }^{\mathrm{c}} P<0.05$ compared to diabetic control group, where the significance was performed by Oneway ANOVA followed by post hoc Dunnett's test. Glibenclamide (GB). Control (C); the values are given in $\mathrm{U} / \mathrm{mg}$ of protein.

TABLE 13: Effect of hexane extract of $P$. canariensis on serum and pancreatic insulin concentration of normal and diabetic mice.

\begin{tabular}{lccc}
\hline Groups & $\begin{array}{c}\text { Before administration } \\
(0 \mathrm{~h})\end{array}$ & $\begin{array}{c}\text { Plasma insulin } \\
(\mu \mathrm{IU} / \mathrm{mL})\end{array}$ & $\begin{array}{c}\text { Pancreatic insulin } \\
(\mu \mathrm{IU} / \mathrm{mL})\end{array}$ \\
\hline Normal control & $3.59 \pm 0.52$ & $3.60 \pm 0.15$ & $25.80 \pm 3.76$ \\
SD control & $0.77 \pm 0.084$ & $1.50 \pm 0.29^{\mathrm{a}}$ & $15.21 \pm 5.43^{\mathrm{a}}$ \\
MD control & $0.76 \pm 0.032$ & ${ }^{\mathrm{d}} 1.61 \pm 0.36^{\mathrm{b}}$ & $15.02 \pm 5.13^{\mathrm{bc}}$ \\
SD + AL & $0.74 \pm 0.019$ & $\mathrm{~d}^{\mathrm{d}} 3.17 \pm 0.51^{\mathrm{b}}$ & $21.24 \pm 6.38^{\mathrm{bc}}$ \\
MD + AL & $0.77 \pm 0.037$ & ${ }^{\mathrm{d}} 3.27 \pm 0.54^{\mathrm{b}}$ & $21.68 \pm 6.18^{\mathrm{bc}}$ \\
SD + glibenclamide $4 \mathrm{mg} / \mathrm{kg}$ & $0.75 \pm 0.070$ & $3.49 \pm 0.34^{\mathrm{b}}$ & $19.35 \pm 3.23^{\mathrm{bc}}$ \\
\hline
\end{tabular}

All values are expressed as mean $\pm \mathrm{SD}, n=6$ values. Plasma insulin values at $0 \mathrm{~h}$ before drug administration are significantly different compared to respective 30 days after drug treatment. Significant difference of diabetic control from normal control ${ }^{\mathrm{a}} P<0.001$. Significant difference of treated groups from diabetic control ${ }^{\mathrm{b}} P<0.01,{ }^{\mathrm{c}} \mathrm{P}<0.05 .{ }^{\mathrm{d}} P<0.01$ when compared with glibenclamide $4 \mathrm{mg} / \mathrm{kg}$ treated group.

significant amounts of $\mathrm{H}_{2} \mathrm{O}_{2}$. In addition, administration of AL-H extract showed increased activities of SOD, GPx, and CAT after 30 days of treatment in STZ rats indicating that the AL-H extract can reduce reactive oxygen free radicals and improve the activities of the antioxidant enzymes [41]. The enhanced activities of the antioxidant enzymes promoted by AL-H protect against STZ-induced damage; therefore, hyperglycemia does not develop. The protection against lipid peroxidation offered by GPx and the effect of AL-H on this enzyme appear to be relevant responses to ROS-induced membrane damage [42].

The effects of the AL-H on transaminase (i.e., ALP, SGPT, and SGOT) activity was also studied in hyperlipemic mice. Transaminases are important enzymes for the study of liver toxicity. ALP is found predominately in the liver, with lesser quantities in the kidneys, heart, and skeletal muscles. As a result, ALP is a more specific indicator of liver inflammation than SGPT and SGOT and may also be elevated in diseases that affect other organs, such as the heart and muscles. Our results indicate that only treatment with the AL-H of hyperlipemic mice reduced the activity of these enzymes, suggesting that this extract effectively reduced the toxic effect on these enzymes. These results suggest that $P$. canariensis prevents oxidative stress, acts as a suppressor of liver cell damages and inhibit, the progression of liver dysfunction induced by chronic hyperglycemia. AL-H extract has a potent effect over antioxidant enzymes activities in pancreatic tissue, enhancing them compared to diabetic control.

$P$. canariensis improves glucose metabolism by reducing insulin resistance and by protecting pancreatic $\beta$-cells from oxidative stress and exhibited excellent hypoglycemic activity, enhancing glucose uptake by adipose and muscle tissues, along with beneficial lipid regulation ability. A reduction in the activities of SGOT, SGPT, and ALP in plasma and an increase in glucokinase and $\mathrm{HK}$ and a decrease in G6Pase indicated the hepatoprotective role. We demonstrated that daily consumption of $P$. canariensis tended to suppress body weight in fatty mice with hypertriglyceridemia. Although the effect of $P$. canariensis is important, it is interesting that $P$. canariensis suppressed body weight without affecting food consumption. P. canariensis possesses lipid lowering effect in obesity-induced mice, as well as its weight-reducing ability. Due to the promising effects of $P$. canariensis in STZ-induced diabetes mice and diet-induced obesity, further studies are sought in order to determine the active principle from this plant. 


\section{Conflict of Interests}

The authors have no conflict of interests to declare.

\section{References}

[1] S.-I. Kang, H.-S. Shin, H.-M. Kim et al., "Anti-obesity properties of a Sasa quelpaertensis extract in high-fat diet-induced obese mice," Bioscience, Biotechnology and Biochemistry, vol. 76, no. 4, pp. 755-761, 2012.

[2] M. Miyata, T. Koyama, T. Kamitani, T. Toda, and K. Yazawa, "Anti-obesity effect on rodents of the traditional japanese food, tororokombu, shaved Laminaria," Bioscience, Biotechnology and Biochemistry, vol. 73, no. 10, pp. 2326-2328, 2009.

[3] S. Colagiuri, "Diabesity: therapeutic options," Diabetes, Obesity and Metabolism, vol. 12, no. 6, pp. 463-473, 2010.

[4] F. I. Achike, N.-H. P. To, H. Wang, and C.-Y. Kwan, "Obesity, metabolic syndrome, adipocytes and vascular function: a holistic viewpoint," Clinical and Experimental Pharmacology and Physiology, vol. 38, no. 1, pp. 1-10, 2011.

[5] E. E. Kershaw and J. S. Flier, "Adipose tissue as an endocrine organ," The Journal of Clinical Endocrinology and Metabolism, vol. 89, no. 6, pp. 2548-2556, 2004.

[6] G. Boden and G. I. Shulman, "Free fatty acids in obesity and type 2 diabetes: defining their role in the development of insulin resistance and $\beta$-cell dysfunction," European Journal of Clinical Investigation, vol. 32, no. 3, pp. 14-23, 2002.

[7] E. J. Gallagher, D. Leroith, and E. Karnieli, "Insulin resistance in obesity as the underlying cause for the metabolic syndrome," Mount Sinai Journal of Medicine, vol. 77, no. 5, pp. 511-523, 2010.

[8] R. Birari, V. Javia, and K. K. Bhutani, "Antiobesity and lipid lowering effects of Murraya koenigii (L.) Spreng leaves extracts and mahanimbine on high fat diet induced obese rats," Fitoterapia, vol. 81, no. 8, pp. 1129-1133, 2010.

[9] I. Melnikova and D. Wages, "Anti-obesity therapies," Nature Reviews Drug Discovery, vol. 5, no. 5, pp. 369-370, 2006.

[10] M. Mukherjee, "Human digestive and metabolic lipases-a brief review," Journal of Molecular Catalysis B, vol. 22, no. 5-6, pp. 369-376, 2003.

[11] D. H. Putnam, P. R. Miller, and P. Hucl, "Potential for production and utilization of annual canarygrass," Cereal Foods World, vol. 41, no. 2, pp. 75-83, 1996.

[12] C. H. O’Neill, G. M. Hodges, and P. N. Riddle, "A fine fibrous silica contaminant of flour in the high oesophageal cancer area of the north-east Iran," International Journal of Cancer, vol. 26, no. 5, pp. 617-628, 1980.

[13] P. Hucl, M. Matus-Cadiz, A. Vandenberg et al., "CDC Maria annual canarygrass," Canadian Journal of Plant Science, vol. 81, no. 1, pp. 115-116, 2001.

[14] A. Merzouki, F. Ed-Derfoufi, and J. Molero-Mesa, "Contribución al conocimiento de la medicina rifeña tradicional lll: fitoterapia de la diabetes en la provincia de Chefchaouen (norte de Marruecos)," ARS Pharmaceutica, vol. 44, no. 1, pp. 59-67, 2003.

[15] M. J. Novas, A. M. Jiménez, and A. O. Asuero, "Determination of antioxidant activity of canary seed infusions by chemiluminescence," Analytical Chemistry, vol. 59, no. 1, pp. 75-77, 2004.

[16] A. P. C. Balbi, K. E. Campos, and M. J. Q. F. Alves, "Hypotensive effect of canary grass (Phalaris canariensis L.) aqueous extract in rats," Revista Brasileira de Plantas Medicinais, vol. 10, no. 3, pp. 51-56, 2008.
[17] F. Martinello, S. M. Soares, J. J. Franco et al., "Hypolipemic and antioxidant activities from Tamarindus indica L. pulp fruit extract in hypercholesterolemic hamsters," Food and Chemical Toxicology, vol. 44, no. 6, pp. 810-818, 2006.

[18] J. Mohammadi and P. Naik, "Evaluation of hypoglycemic effect of Morus alba in an animal model," Indian Journal of Pharmacology, vol. 40, no. 1, pp. 15-18, 2008.

[19] M. Sharma, M. W. Siddique, M. Shamirn, S. Gyanesh, and K. K. Pillai, "Evaluation of antidiabetic and antioxidant effects of seabuckthorn (Hippophae rhamnoides L.)in streptozotocinnicotinamide induced diabetic rats," The Open Conference Proceeding Journal, vol. 2, no. 4, pp. 53-58, 2011.

[20] Y.-C. Chou, Y.-C. Tsai, C.-M. Chen, S.-M. Chen, and J.A. Lee, "Determination of lipoprotein lipase activity in post heparin plasma of streptozotocin-induced diabetic rats by high-performance liquid chromatography with flourescence detection," Biomedical Chromatography, vol. 22, no. 5, pp. 502510, 2008.

[21] M. Li, D. H. Kim, P. L. Tsenovoy et al., "Treatment of obese diabetic mice with a heme oxygenase inducer reduces visceral and subcutaneous adiposity, increases adiponectin levels, and improves insulin sensitivity and glucose tolerance," Diabetes, vol. 57, no. 6, pp. 1526-1535, 2008.

[22] S.-E. Park, M.-H. Cho, J. K. Lim et al., "A new colorimetric method for determining the isomerization activity of sucrose isomerase," Bioscience, Biotechnology and Biochemistry, vol. 71, no. 2, pp. 583-586, 2007.

[23] C. G. Fraga, B. E. Leibovitz, and A. L. Tappel, "Lipid peroxidation measured as thiobarbituric acid-reactive substances in tissue slices. Characterization and comparison with homogenates and microsomes," Free Radical Biology and Medicine, vol. 4, no. 3, pp. 155-161, 1988.

[24] S. Bolkent, R. Yanardag, O. Karabulut-Bulan, and B. Yesilyaprak, "Protective role of Melissa officinalis L. extract on liver of hyperlipidemic rats: a morphological and biochemical study," Journal of Ethnopharmacology, vol. 99, no. 3, pp. 391-398, 2005.

[25] T. L. Kinney LaPier and K. J. Rodnick, "Effects of aerobic exercise on energy metabolism in the hypertensive rat heart," Physical Therapy, vol. 81, no. 4, pp. 1006-1017, 2001.

[26] S. N. Davis and D. K. Granner, "Insulin oral hypoglycaemic agents in the pharmacology of the endocrine pancreas," in The Pharmacological Basis of Therapeutica, J. G. Hardman, L. G. Limbird, S. Goodman, and A. G. Gilman's, Eds., pp. 1701-1704, McMillan, New York, NY, USA, 10th edition, 1996.

[27] E. S. Baginiski, P. P. Foa, and B. Zak, Methods of Enzymatic Analysis, vol. 2, Academic Press, New York, 1969, H. U. Bergmeyer, Ed.

[28] M. M. Bradford, "A rapid and sensitive method for the quantitation of microgram quantities of protein utilizing the principle of protein dye binding," Analytical Biochemistry, vol. 72, no. 1-2, pp. 248-254, 1976.

[29] S. Panserat, E. Capilla, J. Gutierrez et al., "Glucokinase is highly induced and glucose-6-phosphatase poorly repressed in liver of rainbow trout (Oncorhynchus mykiss) by a single meal with glucose," Comparative Biochemistry and Physiology B, vol. 128, no. 2, pp. 275-283, 2001.

[30] M. A. Tranulis, B. Christophersen, A. K. Blom, and B. Borrebaek, "Glucose dehydrogenase, glucose-6-phosphate dehydrogenase and hexokinase in liver of rainbow trout (Salmo gairdneri). Effects of starvation and temperature variations," 
Comparative Biochemistry and Physiology B, vol. 99, no. 3, pp. 687-691, 1991.

[31] J. Folch, M. Lees, and G. H. Sloane-Stanley, "A simple method for the isolation and purification of total lipides from animal tissues," The Journal of Biological Chemistry, vol. 226, no. 1, pp. 497-509, 1957.

[32] P. J. Hissin, J. E. Foley, and L. J. Wardzala, "Mechanism of insulin-resistant glucose transport activity in the enlarged adipose cell of the aged, obese rat. Relative depletion of intracellular glucose transport systems," Journal of Clinical Investigation, vol. 70, no. 4, pp. 780-790, 1982.

[33] S. Iwashita, M. Tanida, N. Terui et al., "Direct measurement of renal sympathetic nervous activity in high-fat diet-related hypertensive rats," Life Sciences, vol. 71, no. 5, pp. 537-546, 2002.

[34] H.-K. Kim, C. Nelson-Dooley, M. A. Della-Fera et al., "Genistein decreases food intake, body weight, and fat pad weight and causes adipose tissue apoptosis in ovariectomized female mice," Journal of Nutrition, vol. 136, no. 2, pp. 409-414, 2006.

[35] M. Kim and Y. Kim, "Hypocholesterolemic effects of curcumin via up-regulation of cholesterol 7a-hydroxylase in rats fed a high fat diet," Nutrition Research Practice, vol. 4, pp. 191-195, 2010.

[36] J.-T. Hwang, I.-J. Park, J.-I. Shin et al., “Genistein, EGCG, and capsaicin inhibit adipocyte differentiation process via activating AMP-activated protein kinase," Biochemical and Biophysical Research Communications, vol. 338, no. 2, pp. 694-699, 2005.

[37] X. Huang, A. Vaag, M. Hansson, J. Weng, E. S. A. Laurila, and L. Groop, "Impaired insulin-stimulated expression of the glycogen synthase gene in skeletal muscle of type 2 diabetic patients is acquired rather than inherited," The Journal of Clinical Endocrinology and Metabolism, vol. 85, no. 4, pp. 15841590, 2000.

[38] S. Karlander, M. Vranic, and S. Efendic, "Mild type II diabetes markedly increases glucose cycling in the postabsorptive state and during glucose infusion irrespective of obesity," Journal of Clinical Investigation, vol. 81, no. 6, pp. 1953-1961, 1988.

[39] L. Pari and M. Amarnath Satheesh, "Antidiabetic activity of Boerhaavia diffusa L.: effect on hepatic key enzymes in experimental diabetes," Journal of Ethnopharmacology, vol. 91, no. 1, pp. 109-113, 2004.

[40] T. Gohil, N. Pathak, N. Jivani, V. Devmurari, and J. Patel, "Treatment with extracts of Eugenia jambolana seed and Aegle marmelos leaf extracts prevents hyperglycemia and hyperlipidemia in alloxan induced diabetic rats," African Journal of Pharmacy and Pharmacology, vol. 4, no. 5, pp. 270-275, 2010.

[41] S. Karlander, M. Vranic, and S. Efendic, "Mild type II diabetes markedly increases glucose cycling in the postabsorptive state and during glucose infusion irrespective of obesity," Journal of Clinical Investigation, vol. 81, no. 6, pp. 1953-1961, 1988.

[42] B. Matkovics, M. Kotorman, I. Sz. Varga, D. Quy Hai, and C. Varga, "Oxidative stress in experimental diabetes induced by streptozotocin," Acta Physiologica Hungarica, vol. 85, no. 1, pp. 29-38, 1998. 


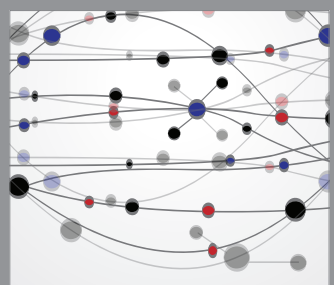

The Scientific World Journal
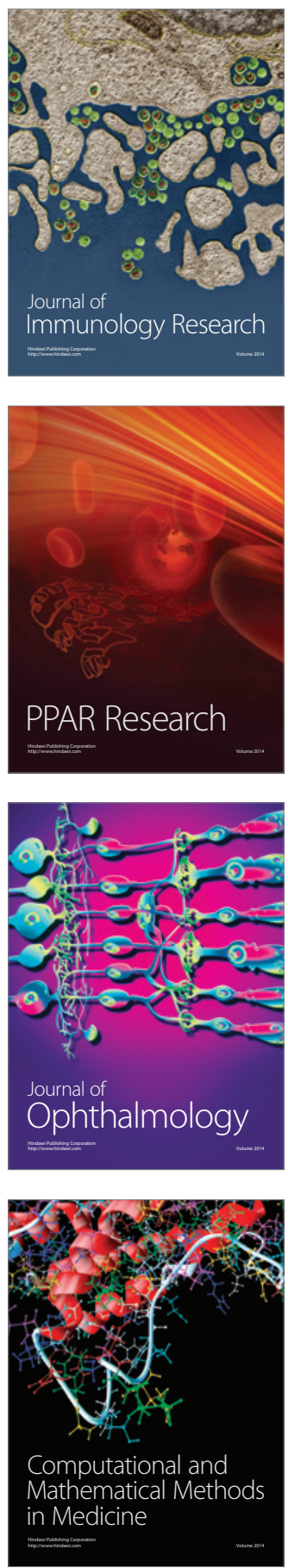

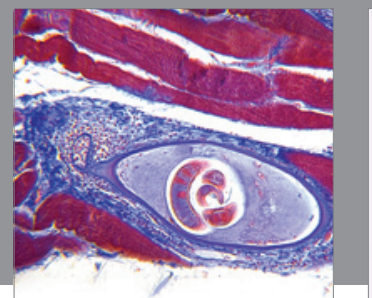

Gastroenterology

Research and Practice
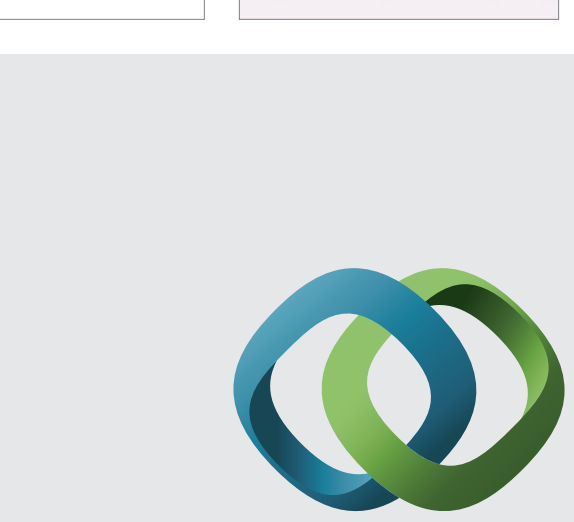

\section{Hindawi}

Submit your manuscripts at

http://www.hindawi.com
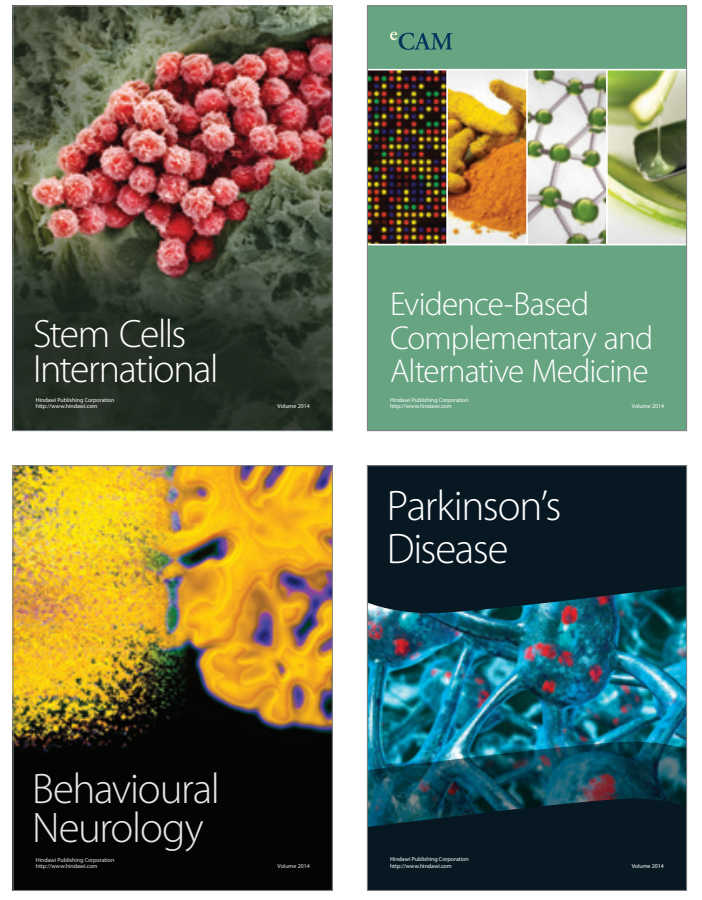
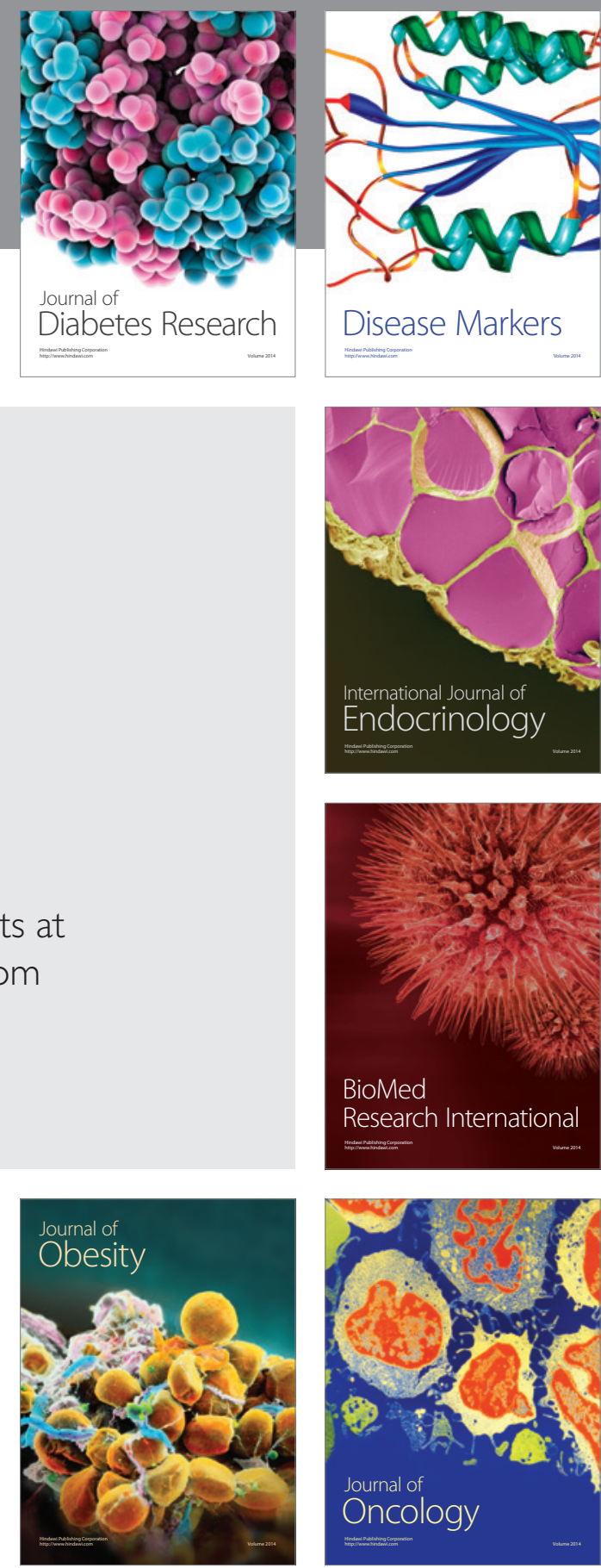

Disease Markers
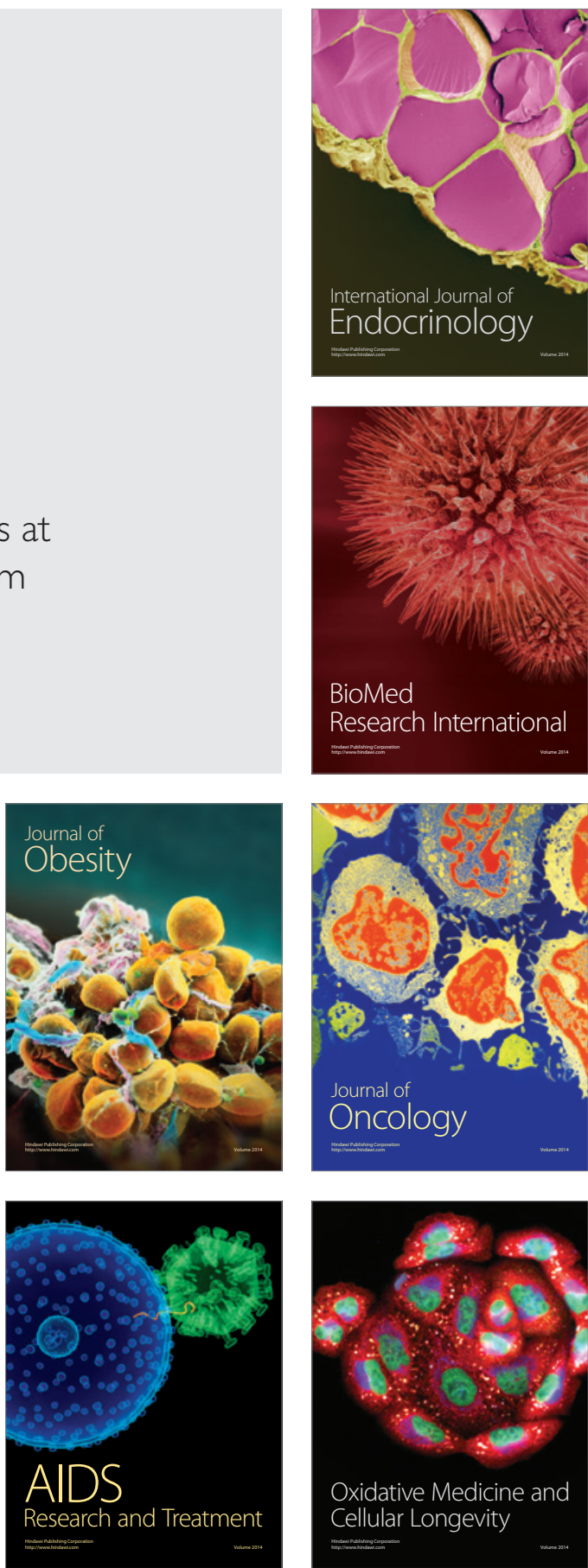